\title{
Geologic Map of Mount Gareloi, Gareloi Island, Alaska
}

\author{
By Michelle L. Coombs, Robert G. McGimsey, and Brandon L. Browne
}

Pamphlet to accompany

Scientific Investigations Map 3145

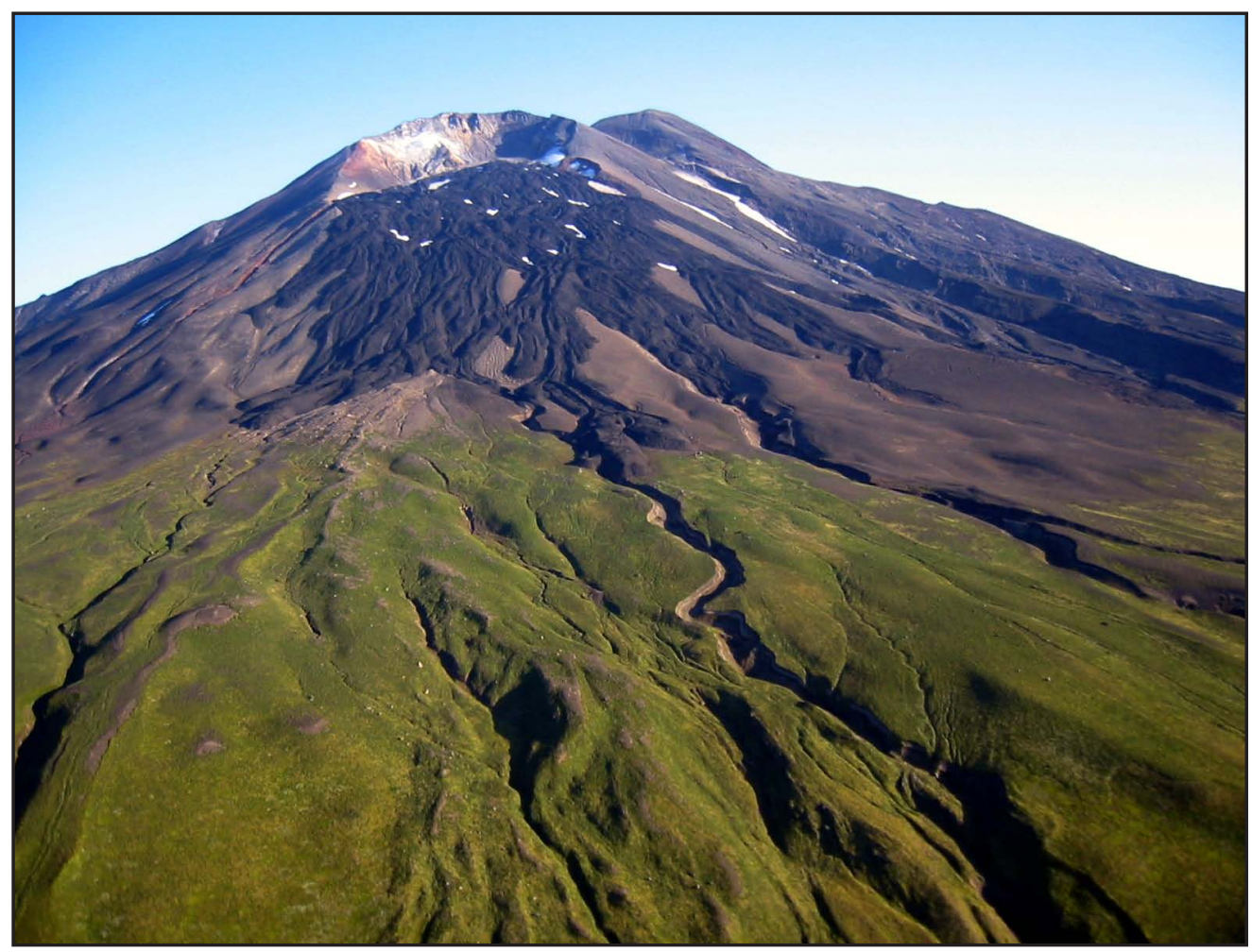

Mount Gareloi's south summit, looking north. Black sinuous lava flows, erupted sometime between 1950 and 1980, pour out of the crater floor. The volcano's south flank is covered in pyroclastic deposits from the 1929 eruption, and older lava flows that are vegetated are visible in the foreground. (Photograph by R. McGimsey, August 30, 2003). 
This page intentionally left blank 


\section{Contents}

Introduction

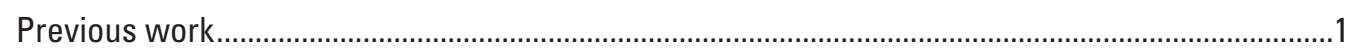

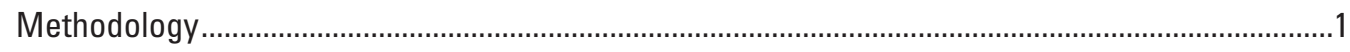

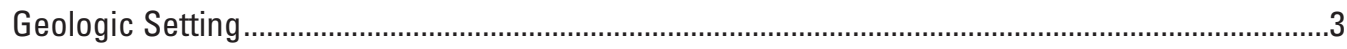

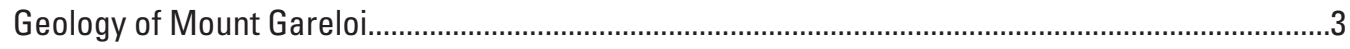

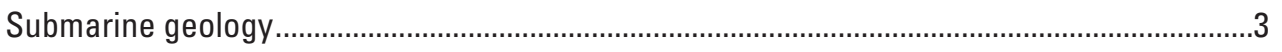

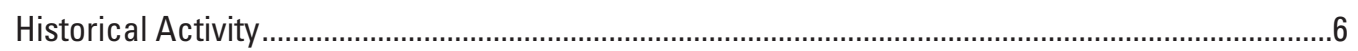

1929 eruption

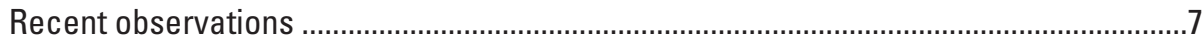

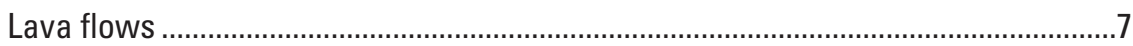

Pyroclastic deposits .............................................................................................

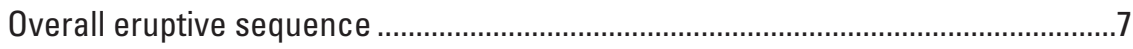

1950-1980 South Peak effusive eruption ...............................................................................

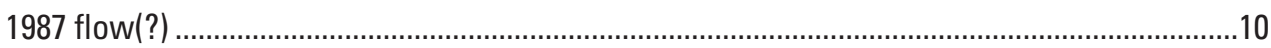

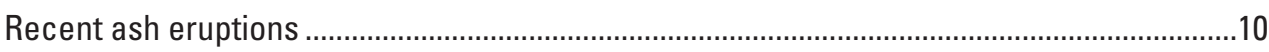

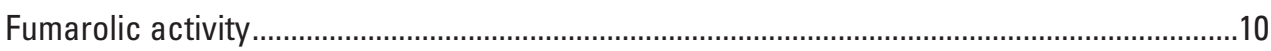

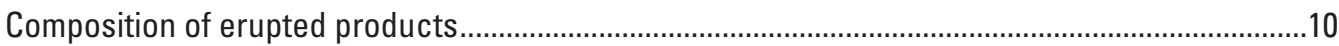

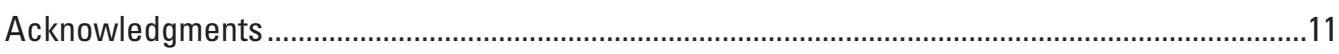

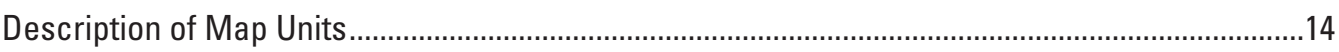

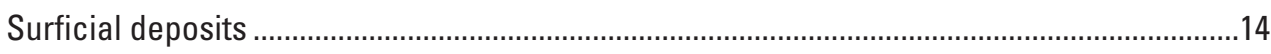

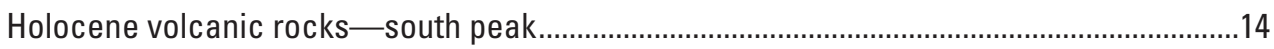

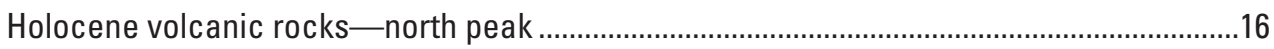

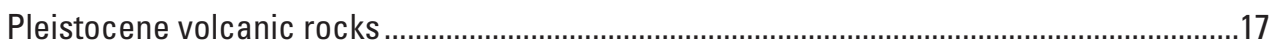

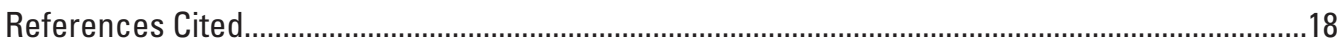

Appendix 1. Whole-rock compositions of rocks from Mount Gareloi............................................18

Figures

1. A, Location of Mount Gareloi on Gareloi Island; B, Geographic setting of Mount Gareloi

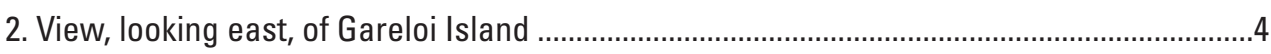

3. View, looking northwest, of north peak............................................................................

4. Map showing shaded-relief topography and bathymetry for Gareloi Island and the surrounding seafloor ...............................................................................................

5. $A$, Photograph, looking north, of 1929 craters, lava flows, and pyroclastic deposits on southeast flank of south peak; $B$, Explanation of geologic features seen in $A$.............6

6. Stratigraphic sections showing deposits from the 1929 eruption of Mount Gareloi.............8

7. Diagram showing correlations between pyroclastic deposits, lava flows, and debris-flow deposits formed during 1929 eruption .........................................................................

8. Photograph of debris-avalanche deposit (unit d29) ...........................................................

9. View of lava flow(?) formed during 1987 eruption ..........................................................10

10. Variation diagrams showing compositions of Mount Gareloi rocks compared to other

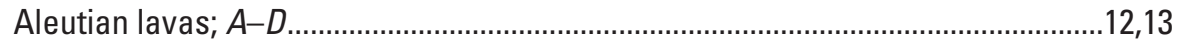

Tables

1. ${ }^{40} \mathrm{Ar} /{ }^{39} \mathrm{Ar}$ ages for Mount Gareloi lavas, Gareloi Island, Alaska ..........................................

2. ${ }^{14} \mathrm{C}$ age on soil beneath tephra section on north flank of Mount Gareloi, Gareloi Island, Alaska...... 
This page intentionally left blank 


\section{Introduction}

Gareloi Island (lat $51.7^{\circ} \mathrm{N}$., long $178.8^{\circ} \mathrm{W}$.) is located in the Delarof Islands group of the Aleutian Islands, approximately 2,000 km west-southwest of Anchorage and $150 \mathrm{~km}$ west of Adak, the westernmost town in Alaska (fig. 1). This small ( 8$\mathrm{x} 10-\mathrm{km}$ diam), uninhabited island is constructed exclusively of eruptive products from Mount Gareloi volcano, a Pleistocene and Holocene, steep-sided, composite stratocone that rises 1,573 $\mathrm{m}(5,161 \mathrm{ft})$ above sea level (asl). Mount Gareloi has been one of the most active Aleutian volcanoes since its discovery by the Bering expedition in the 1740s (Miller and others, 1998), though, because of its remote location, detailed observations of eruptive activity have been scant.

As part of an effort to both monitor and study all historically active volcanoes in Alaska, the Alaska Volcano Observatory (AVO) undertook a field program at Mount Gareloi in the summer of 2003. During a month-long period, seismic networks were installed at Mount Gareloi and the neighboring Tanaga volcanic cluster. During this time, we undertook the first geologic field study of the volcano since Robert Coats visited Gareloi Island for four days in 1946. Understanding the geology of this relatively small island is important from a hazards perspective, because Mount Gareloi lies beneath a heavily trafficked air route between North America and Asia and has frequently erupted airborne ash since 1760. At least two landslides from the island have deposited debris on the sea floor; thus, landslide-generated tsunamis are also a potential hazard (Coombs and others, 2007). Since seismic instruments were installed in 2003, they have detected small but consistent seismic signals from beneath Mount Gareloi's edifice, suggesting an active hydrothermal system (Caplan-Auerbach and Prejean, 2005). Mount Gareloi is also important from the standpoint of understanding subduction-related volcanism, because it lies in the western portion of the volcanically active arc, where subduction is oblique to the arc front. Understanding the compositional evolution of Mount Gareloi fills a spatial gap in along-arc studies (for example, Kelemen and others, 2003; Kay and Kay, 1994; Singer and others, 2007).

\section{Previous Work}

Prior to our field work in 2003, only one other geologic party had visited Gareloi Island: Robert Coats and his field assistant Will Thompson spent four days there in 1946. Their brief field work, conducted on foot, led to a preliminary geologic map and a general outline of the eruptive history of Mount Gareloi (Coats, 1959). His field work on Gareloi and neighboring islands is also briefly described elsewhere (Coats, 1947, 1950, 1956).

Coats described two main phases of volcanic activity on Gareloi Island, separated by a considerable period of volcanic quiescence. The older of the two units was thought to be Pleistocene in age, because of the presence of U-shaped valleys probably eroded by ice, and consists of intercalated lava flows and pyroclastic deposits. These older rocks are displayed in particularly prominent cliffs on the island's southwest coast. Holocene eruptive products are primarily lava flows. Coats also mapped the products of a 1929 fissure eruption on the volcano's south flank. This eruption, observed by a resident of Atka (Finch, 1931), produced lava flows, a series of craters, and a pyroclastic apron that covers the south half of the island. Coats obtained no geochemical analyses but thought the eruptive products to be basaltic and andesitic. The 1929 eruption of Mount Gareloi was noted by Nakamura (1977) as an example of a fissure that is aligned with plate convergence and, thus, indicative of tectonic stress orientation.

In 2005, a research cruise in the western Aleutian Islands dredged samples from seafloor volcanoes and collected multibeam bathymetry and sidescan data of the seafloor. During the cruise, two dredges were conducted on satellite vents offshore of Gareloi Island, and the seafloor to the north and east was mapped. This provided the first detailed information about the submarine portion of Mount Gareloi (Coombs and others, 2007).

On the basis of 2003 field work, Coombs and others (2008) described the volcanic hazards associated with eruptions of Mount Gareloi and concluded that the primary hazard is airborne ash from relatively frequent explosive eruptions, although much less frequent edifice collapses also send debris into the sea and produce at least localized tsunamis.

\section{Methodology}

Field work for this geologic study was conducted in August and September of 2003, in conjunction with the installation of a seismic network on Mount Gareloi. Access to the island was aboard the 86-ft Maritime Maid, a helicopter-supporting vessel contracted from Maritime Helicopters. Using the boat and helicopter allowed us to cover much of the island in six and a half days of field work. A helicopter overflight in 2005 allowed observations of summit features, but no landings were made.

The Gareloi Island Army Map Service topographic map sheet, at 1:25,000 scale, was used as a field mapping base. Field mapping was supplemented by analysis of aerial photographs taken in August 2002, as well as by imagery provided by the U.S. Geological Survey (USGS). A digital geologic map was created through a combination of digitizing scanned field mapping and mapping directly on digital imagery. All digital mapping was performed using ESRI ArcGIS 8.3-9.3 software.

Rock samples were prepared for geochemical analysis, ${ }^{40} \mathrm{Ar} /{ }^{39} \mathrm{Ar}$ geochronology, and thin section preparation upon returning from the field in the fall of 2003. Major and trace element whole-rock analyses (appendix 1, available at http://pubs. usgs.gov/sim/3145) were performed using XRF and ICP-MS techniques at the GeoAnalytical Laboratory at Washington State University. ${ }^{40} \mathrm{Ar} /{ }^{39} \mathrm{Ar}$ dating (table 1) was performed by A. Calvert at the USGS in Menlo Park, CA. One soil sample was dated using traditional ${ }^{14} \mathrm{C}$ techniques at the Geochronological Laboratory in Cambridge, MA. 

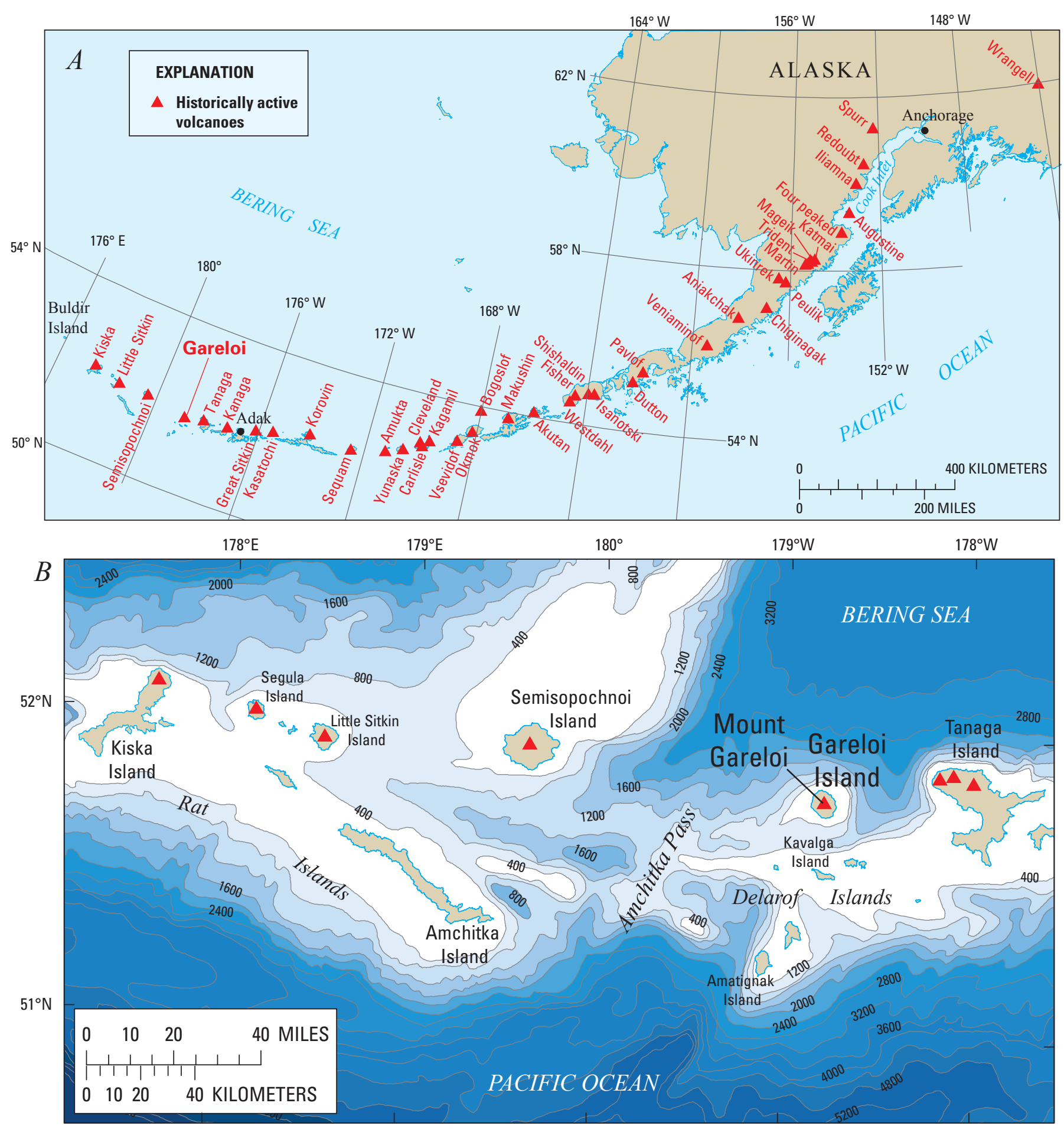

Figure 1. $A$, Location of Mount Gareloi on Gareloi Island in relation to other historically active volcanoes of Alaska (as listed in Miller and others, 1998). B, Geographic setting of Mount Gareloi, Gareloi Island, and nearby islands, Alaska. Bathymetric contour interval, $400 \mathrm{~m}$. 
Table 1. ${ }^{40} \mathrm{Ar} /{ }^{39} \mathrm{Ar}$ ages for Mount Gareloi lavas, Gareloi Island, Alaska.

[Samples irradiated at USGS TRIGA reactor using 27.87 Ma Taylor Creek sanidine as a neutron flux monitor. Preferred ages in bold. MSWD, mean square of weighted deviates]

\begin{tabular}{|c|c|c|c|c|c|c|c|c|c|}
\hline \multirow[b]{2}{*}{ Sample No. } & \multirow[b]{2}{*}{ Material } & \multicolumn{3}{|c|}{${ }^{40} \mathrm{Ar} /{ }^{39} \mathrm{Ar}$ Weighted mean plateau age } & \multicolumn{4}{|c|}{${ }^{40} \mathrm{Ar} /{ }^{39} \mathrm{Ar}$ isotope correlation (isochron) age } & \multirow{2}{*}{$\frac{{ }^{40} \mathrm{Ar} /{ }^{39} \mathrm{Ar} \text { total gas }}{\text { Age }(\mathrm{ka})}$} \\
\hline & & Age (ka) & $\%^{39} \mathrm{Ar}\left[\right.$ steps, $\left.{ }^{\circ} \mathrm{C}\right]$ & MSWD & Age (ka) & $\%^{39} \mathrm{Ar}\left[\right.$ steps, $\left.{ }^{\circ} \mathrm{C}\right]$ & MSWD & ${ }^{40} \mathrm{Ar} /{ }^{36} \mathrm{Ari}$ & \\
\hline 03GRBB32 & Basalt & $-10.3 \pm 3.6$ & $92.8[550-990]$ & 2.87 & $1.8 \pm 4.5$ & $92.8[550-990]$ & 2.07 & $292.4 \pm 2.0$ & $-17.5 \pm 3.3$ \\
\hline 03GRBB38 & Basalt & $6.1 \pm 1.0$ & $97.3[600-1100]$ & 0.5 & $7.0 \pm 1.8$ & $97.3[600-1100]$ & 0.51 & $293.1 \pm 1.9$ & $3.2 \pm 1.3$ \\
\hline 03GRGM20 & Basalt & $0.3 \pm 1.4$ & $100[550-1150]$ & 0.94 & $1.6 \pm 2.4$ & $100[550-1150]$ & 1.27 & $295.0 \pm 1.7$ & $-0.9 \pm 1.6$ \\
\hline
\end{tabular}

\section{Geologic Setting}

Mount Gareloi is located in the westernmost volcanically active portion of the Aleutian Arc (fig. 1), which is formed by subduction of the Pacific plate beneath the Bering Sea portion of the North American plate. Whereas subduction is normal to the arc farther east, it becomes oblique to the west due to the curvature of the arc (Minster and Jordan, 1978). Subduction of Paleocene oceanic crust in the western arc occurs obliquely at a rate of approximately $8 \mathrm{~cm} / \mathrm{yr}$ ( $4 \mathrm{~cm} / \mathrm{yr}$ orthogonal component; Engebretson and others, 1985).

The Aleutian Ridge, which forms the platform upon which the Quaternary stratovolcanoes sit, is built of predominantly Eocene igneous and sedimentary rocks that were formed during the first, highly active phase of Aleutian Arc growth (Scholl and others, 1987). The ridge has been part of an active volcanic arc since at least 46 m.y. (Jicha and others, 2006), and much of the mass of the ridge had been formed by $37 \mathrm{Ma}$ (Scholl and others, 1987). The current tectonic configuration and active arc have existed since about $5 \mathrm{Ma}$, when an increase in the subduction rate led to increased magma genesis and volcanism (Scholl and others, 1987).

Whereas Mount Gareloi is aligned with neighboring Quaternary stratovolcanoes to the east and west, the Aleutian Ridge is irregularly shaped in this area, placing Mount Gareloi slightly north of the main ridge platform (fig. $1 B$ ). Geist and others (1988) proposed that the Aleutian Ridge comprises a series of rotated blocks. Mount Gareloi sits north of the Delarof Block, which is bounded by Amchitka Pass to the west and informally named Adak canyon to the east. Because of this configuration, it sits on a pedestal presumably created by its own constructional vigor that rises from at least $2,400 \mathrm{~m}$ below sea level (bsl) on the west, north, and east.

\section{Geology of Mount Gareloi}

On the basis of appearance and correlation with neighboring stratovolcanoes, the oldest rocks on Gareloi Island are presumably Pleistocene, though no rocks from what appear to be the oldest outcrops along the southwest coast have been sampled. These older rocks crop out as deeply dissected stacks of lavas and pyroclastic deposits that form wedge-shaped map sectors on the southwest, southeast, and northeast flanks (Coats, 1959). Holocene lavas, most that are little modified by erosion, have filled low topography between these older sectors and, in some places, spill over older erosional surfaces (fig. 2). The northwestern and eastern portions of the older edifice appear to have been incised by two sector collapses, on the basis of their subaerial geomorphology and offshore debris-avalanche deposits (Coombs and others, 2007). The eastern scar is about $2 \mathrm{~km}$ across, reaches from north peak's summit to the coastline, and is currently $100 \mathrm{~m}$ deep relative to the unaffected surfaces to either side (fig. 3). The northwest sector scar is broader, 5 $\mathrm{km}$ wide at its base, and currently as deep as $120 \mathrm{~m}$. Both were likely deeper prior to infilling by younger lavas.

Most recognized Holocene eruptions from Mount Gareloi appear to have occurred from one of two summits, north peak and south peak, which are separated by a 500 -m-wide saddle at $4,650 \mathrm{ft}$ asl. North peak is the island's true topographic high point and possesses an enclosed crater at least $70 \mathrm{~m}$ deep. North peak's intracrater eruptive stratigraphy is abruptly interrupted by near-vertical local unconformities on the northwest wall, which represent a possible collapse scar that has since been filled. South peak, 4,995 ft asl, has a south-facing, 300-m-wide crater formed by the partial collapse of its crater wall (likely during the 1929 eruption) and contains several active fumaroles.

The island has been significantly modified by recent eruptive activity, most notably the 1929 eruption and a lava flowproducing eruption that occurred sometime between 1950 and 1980. The products of these eruptions are discussed in more detail in the Historical Activity section. In addition to these specific events, numerous recent eruptions have produced a blanket of coarse tephra, included in map units pnp and psp, that covers the summit areas. Some unmapped tephras are locally preserved on the volcano's lower flanks, but they are poorly exposed. A soil near the base of a 120 -cm-thick, tephra-soil section on the north flank yielded a ${ }^{14} \mathrm{C}$ date of $1,090 \pm 70 \mathrm{yr}$ B.P. (table 2). This section contains nine tephra layers ranging from thin, fine ash layers to a 10 - to $16-\mathrm{cm}$-thick scoria lapilli bed.

\section{Submarine Geology}

Unlike most other Aleutian volcanoes, Mount Gareloi is located slightly north of the summit plateau of the Aleutian Ridge and sits upon its own constructional pedestal that rises 


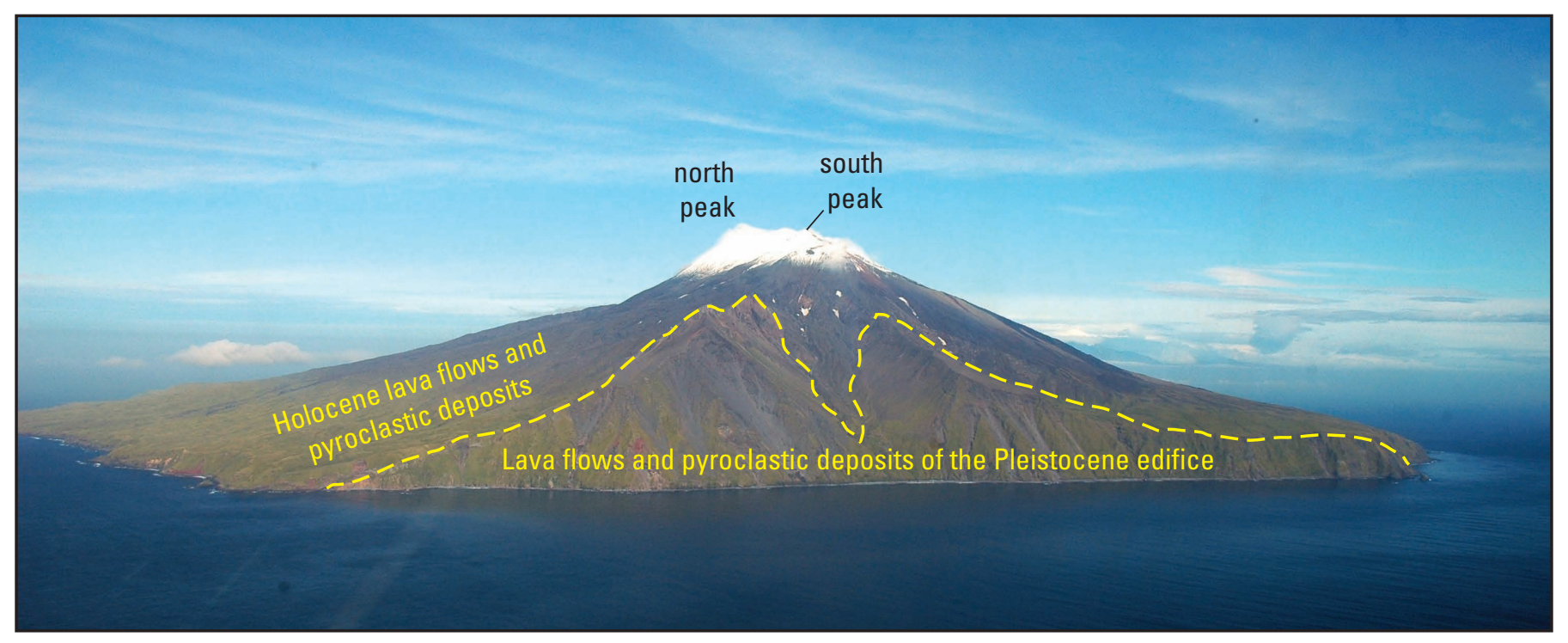

Figure 2. View, looking east, of Gareloi Island. Photograph by M.L. Coombs, USGS, October 2005.

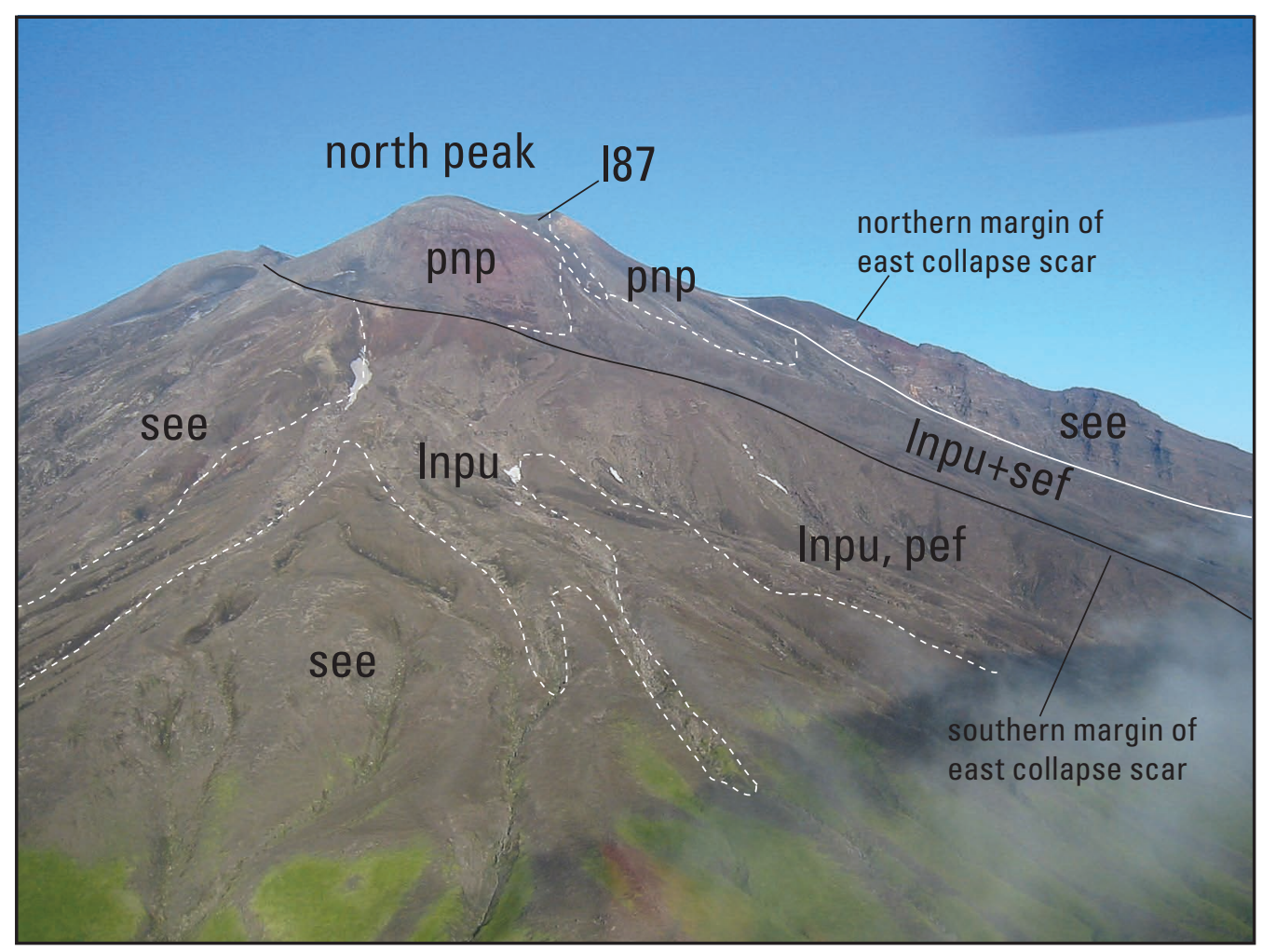

Figure 3. View, looking northwest, of north peak. Lavas and pyroclastic-flow deposits of units Inpu and pef are delineated in the foreground. North peak is built in a collapse scar incised into rocks of unit see. Photograph by M.L. Coombs, USGS, August 2003.

Table 2. ${ }^{14} \mathrm{C}$ age on soil beneath tephra section on north flank of Mount Gareloi, Gareloi Island, Alaska. [Analysis performed at Geochron Laboratories, Cambridge, MA. Age referenced to year A.D. 1950]

\begin{tabular}{ccc}
\hline Sample No. & Age, in ${ }^{14}$ C yr B.P. & \multicolumn{1}{c}{ Material } \\
\hline 03GRMV12E & $1,090 \pm 70$ & $\begin{array}{l}\text { Soil immediately below 118-cm-thick tephra-soil sequence with } \sim 8 \\
\text { tephra-fall layers, on east side of gully wall }\end{array}$ \\
\hline
\end{tabular}




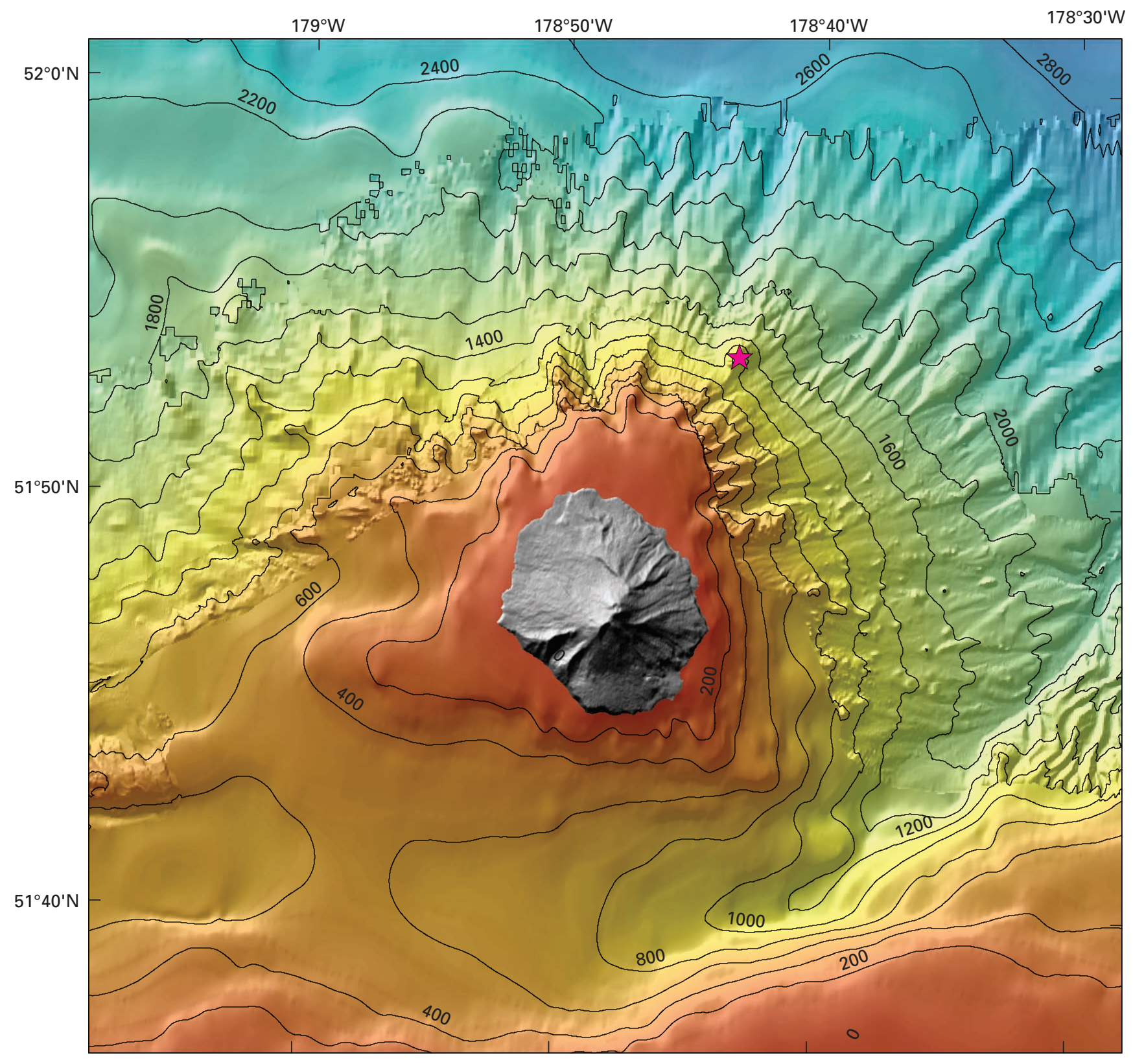

Figure 4. Map showing shaded-relief topography (in gray) and bathymetry (color-scaled for depth) for Gareloi Island and the surrounding seafloor. Bathymetric contour interval is $200 \mathrm{~m}$. Bathymetry dataset has been merged from 1:400,000-scale map (Nichols and Perry, 1966) and multibeam data (Coombs and others, 2007). Smoother areas are typically lacking in the higher resolution multibeam data. Subaerial topography is from the Shuttle Radar Topography Mission (Gesch and others, 2006). Star marks the location of a submarine flank cone that was dredged in 2005 (G. Yogodzinski, personal commun., 2005).

from 2,600 $\mathrm{m}$ bsl on the north and east (fig. 4). Submarine debris fields are present east and north-northwest of Gareloi Island (Coombs and others, 2007). Apparent in GLORIA seafloor sidescan imagery, debris-avalanche deposits form two long lobes north-northwest of the island, and a stubbier, rougher debris lobe to the northwest partially overlaps these. The debrisavalanche deposit to the east of the island is smaller, widening seaward from a narrow zone near the shoreline to about $13 \mathrm{~km}$ across at its distal end, about $13 \mathrm{~km}$ from shoreline. The area is just downslope of the east scar in the subaerial edifice. The age of this deposit is unknown but is likely middle or late Holocene, based on the lack of sediment cover and the sharp morphology of the subaerial collapse scar.

The submarine flank to the northeast, which lies immediately off an inactive sector of the subaerial volcano, is characterized by closely spaced canyons that form smooth, uniform ramparts. This morphology is consistent with being downslope from a relatively inactive portion of the subaerial volcano. A shallow shelf connects the island to the main Aleutian Ridge to the south, but high resolution bathymetry is lacking for this area. 
A conical feature off the island's northeast flank is apparently a constructional cone on the flank of Mount Gareloi and was dredged in 2005 (G. Yogodzinski, personal commun., 2005).

\section{Historical Activity}

Mount Gareloi has been relatively active during historical times, with 19 reports of eruptive activity since 1760 (Miller and others, 1998). Of these, four may be considered questionable, and some can be lumped into periods of continuous activity. Below, we describe the recent eruptions that have resulted in mappable deposits on the island. For a full account of historical activity, see Coombs and others (2008).

\section{Eruption}

The largest historical eruption at Mount Gareloi occurred in 1929. The eruption is notable for its size, its unusual eruptive style, and the composition of the erupted material. This explosive eruption formed a $4.3-\mathrm{km}$-long, south-southeast-trending fissure of 13 aligned craters, reaching from the summit of

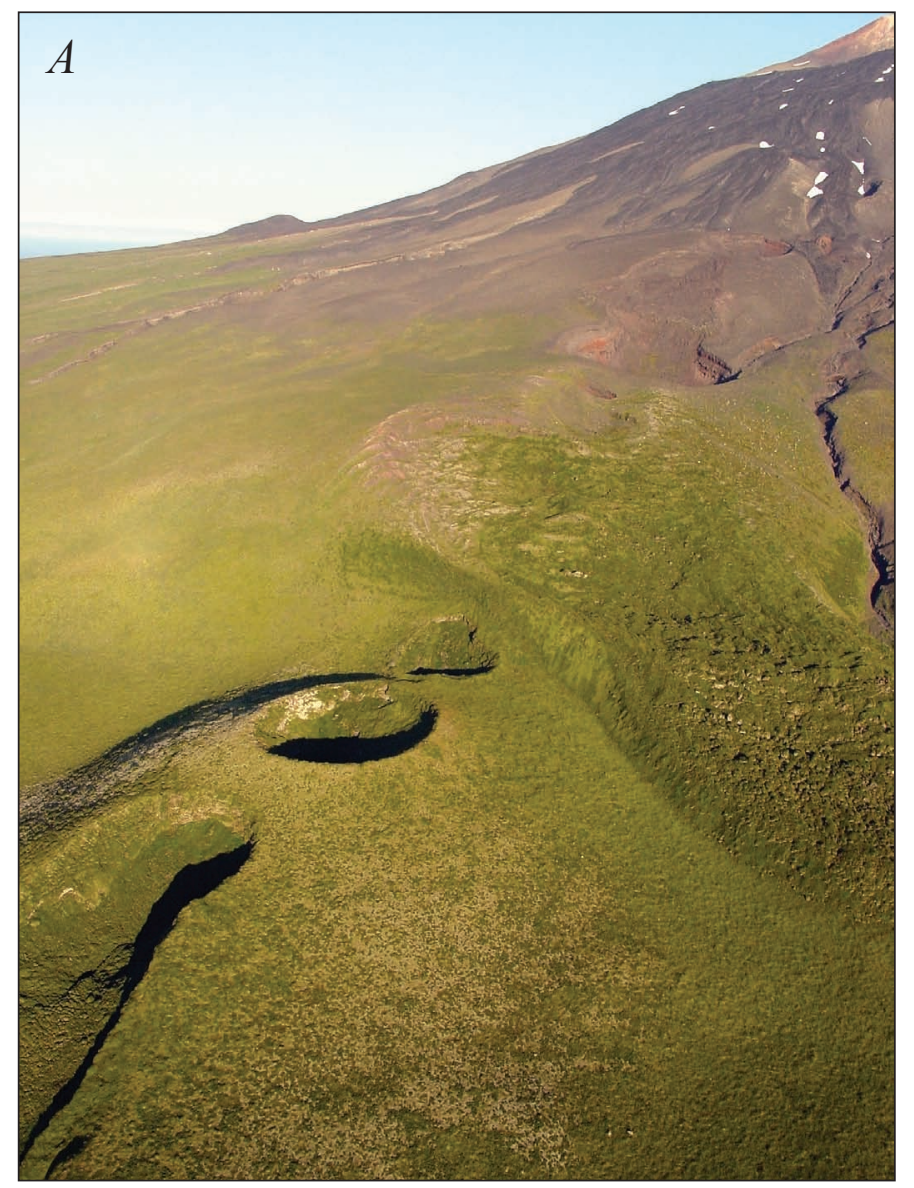

south peak down to the southeast shoreline (fig. 5). The craters individually range from 80 to $1,600 \mathrm{~m}$ in diameter. The eruption also produced a substantial blanket of pyroclastic deposits on the volcano's south flank (unit p29).

The details of the eruptive sequence were first described by Coats (1959, p. 252), who summarized the first-hand observations of a resident of Atka, William H. Dirks, Sr.: "In April of 1929 , there was an eruption. A terrible quake... split the mountain from its crater right to the beach. Ashes fell, completely covering their cabins and boats..." Coats further elaborated on the series of events from observations of the deposits, which were 17 years old when he visited the island and were still unmodified by either vegetation or further eruptive activity. According to his chronology, the eruption caused the excavation of a series of explosion craters along a the south-southeasttrending fissure (fig. 5). The eruption began with formation of the south peak crater, followed by excavation of the lower craters, explosive eruption of tephra, and effusion of lava flows from the lower craters. Coats (1959) notes that, in 1946, crater 10 was filled with a milky blue-green lake. Coats (1956) describes a blanket of ash on Ogliuga Island, $18 \mathrm{~km}$ southsoutheast of Gareloi Island, as $5.5 \mathrm{ft}$ thick, and attributes it to Mount Gareloi on the basis of its "freshness."

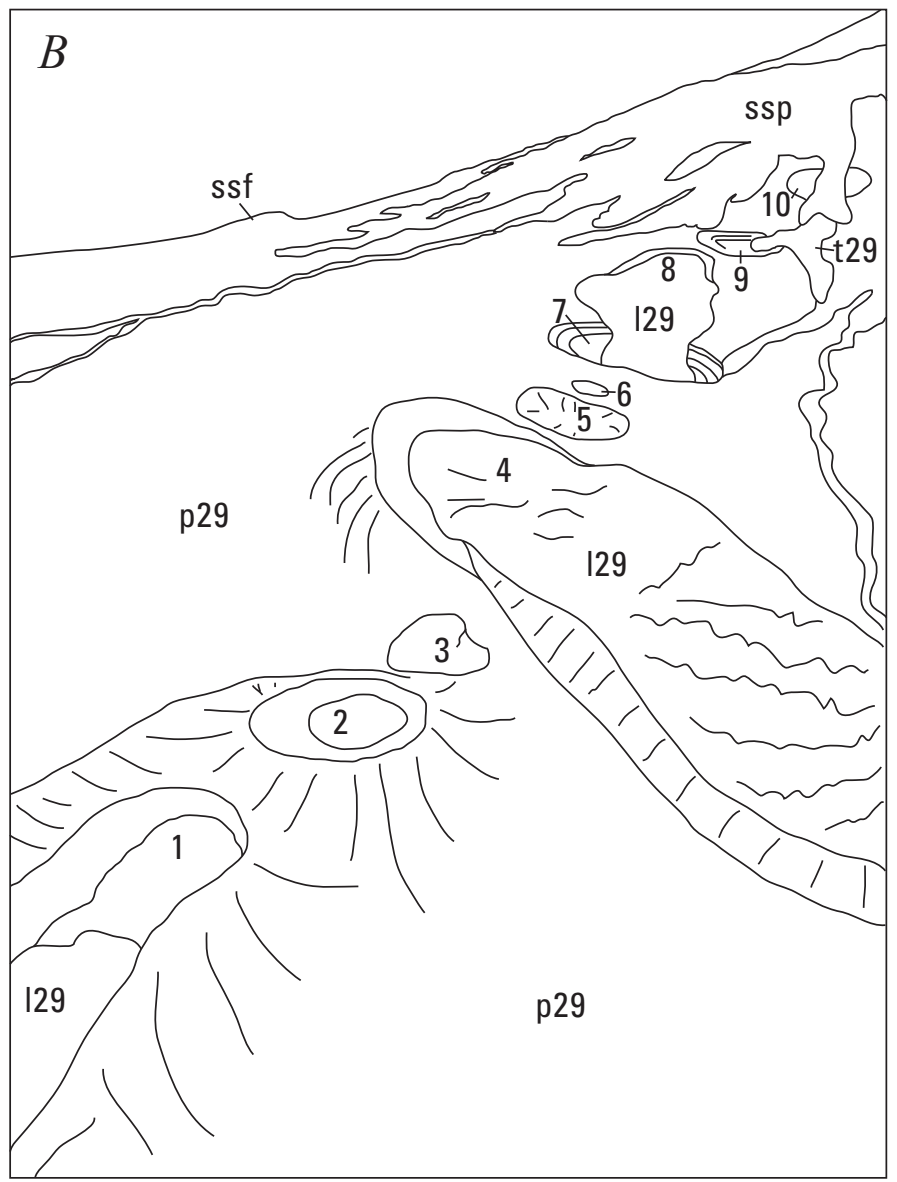

Figure 5. A, Photograph, looking north, of 1929 craters, lava flows, and pyroclastic deposits on southeast flank of south peak. Photo by R.G. McGimsey, USGS, August 2003. B, Explanation of geologic features seen in $A$. Numbers refer to craters formed during 1929 eruption, and units are described in the text. 


\section{Recent Observations}

By the time of our field work in 2003, surprisingly thick vegetation had covered the 1929 lava flows and pyroclastic deposits below approximately $1,300 \mathrm{ft}$ asl. In our limited time on the island, we were able to visit several exposures of 1929 eruptive products (fig. 6). Good exposures in beach cliffs along the south coast and in gully walls, not yet examined, would allow for substantial additional refinement of the stratigraphy presented here.

In addition, we modified the crater numbering scheme of Coats (1959) upon discovery of several additional features. We mapped 16 numbered craters, starting with crater 1 near the coast and crater 16 at the summit of south peak (figs. 5, 6). These form a nearly linear southeast alignment. The craters vary in size and morphology, and some have been completely obscured by 1929 lava (for example, crater 4) or lava from a later eruption (craters 11 and 12 are completely covered by lavas of unit ssp). Some craters $(1,2)$ have substantial tephra cones indicating that they were vents, whereas others appear to be collapse features (craters $3,5,6$ ).

\section{Lava Flows}

Of the visible craters, three have lava flows emanating from them, another lava flow extends from beneath 1950-1980 lava flows between craters 9 and 10, and crater 9 has 1929 lava exposed within its walls. The flow from crater 1 fans out from the vent and forms a lava delta at the coastline; it is underlain by unit p29 (see following) but is not overlain by fall deposits (fig. 6). The flow from crater 4 is the most voluminous of the eruption, wholly filling the crater and spreading to the east. No obvious fall deposits were observed on the flow's incredibly rugged, vegetated surface. A lava flow effused from crater 8 , filling a subtle depression before finally spilling into crater 7. A fourth lava flow issued from a now-covered vent between craters 9 and 10. Informally termed the "wishbone flow" because of its characteristic shape, it splits into two fingers, one of which spills into crater 9. All 1929 lavas have rubbly tops and are as much as several meters thick.

Chemical analysis (appendix 1) shows that lavas from craters 1,4 , and 8 are all compositionally similar latites, with 57.8 to $58.7 \mathrm{wt}$. percent $\mathrm{SiO}_{2}$, and have been assigned to unit 129. Lava flows exposed in the wall of crater 9 and the wishbone flow are trachytes with 60.5 to 61 wt. percent $\mathrm{SiO}_{2}$ and are labeled unit t29. Both latites and trachytes have similar mineralogy, including plagioclase, clinopyroxene, opaques, and olivine in decreasing order of abundance; amphibole was found in trace amounts. Samples of both rock types typically contain about 10 volume percent phenocrysts on a void-free basis. The volume of effused lava is roughly $1.7 \mathrm{M} \mathrm{m}^{3}$, assuming an average lavaflow thickness of $4 \mathrm{~m}$.

\section{Pyroclastic Deposits}

Fall deposits from the 1929 eruption cover a sector of the southeast flank, smoothing underlying lava flows. No tephras that appear to correlate with those on the southeast flank were found on other flanks of the volcano. Whereas the surface of the deposit is mostly covered with vegetation, erosion has cut some severalmeter-deep gullies, exposing stratigraphy (see cover photograph).

Two dominant clast types were present in 1929 pyroclastic deposits: buff- to pinkish-colored pumice and dark-gray scoria. Banded juvenile clasts and dense lava-like lithics were minor lithologies. Chemical analysis of several clasts from the fall deposits indicate that the pumice is trachytic, with 60.1 to 60.7 wt. percent $\mathrm{SiO}_{2}$ and 8.7 to 9.3 wt. percent total alkalis. Scoria clasts are latites, with 58.3 to 58.8 wt. percent $\mathrm{SiO}_{2}$ and 8.1 to 8.5 wt. percent total alkalis. The pumice and scoria essentially overlap compositionally and mineralogically with trachyte and latite lavas of units 29 and 129 , respectively.

At site 03GRBB16, the 1929 pyroclastic deposits are at least $7 \mathrm{~m}$ thick; our measured section did not reach the base (fig. 6). Pyroclastic deposits are dominated by clast-supported fall deposits that are generally pumice rich at the base and scoria rich at the top and that are interbedded with minor matrix-supported pyroclastic-flow deposits. The eruption's total volume is unknown, because much of the pyroclastic material was deposited offshore. The volume of subaerial pyroclastic deposits is approximately $16 \mathrm{M} \mathrm{m}^{3}$, assuming an average thickness of $3 \mathrm{~m}$. Combined with lava volume, the subaerial volume of eruptive products is approximately $18 \mathrm{M} \mathrm{m}^{3}$.

\section{Overall Eruptive Sequence}

Based on both stratigraphic sections (fig. 6) and compositional correlation between lava flows and pyroclastic deposits, the general emplacement sequence for the 1929 eruption follows (fig. 7): (1) a possible pyroclastic surge, forming a deposit consisting of pumice blocks as much as $70 \mathrm{~cm}$ in diameter in a sandy pink-brown matrix; (2a) tephra fall of mostly trachyte pumice with minor latite scoria; $(2 \mathrm{~b})$ thin pyroclastic flows interbedded within 2a; (3) effusion of trachyte lava from (at least) crater 10; (4) tephra fall of roughly equal proportions latite scoria and trachyte pumice; (5) latite-scoria-rich tephra fall; (6) latite lava flows interbedded with latite-scoria tephra fall; and (7) debris flows (fig. 8). We do not know the order in which the craters were formed, but, because latite lava flows are thought to have effused later in the eruption and they are from the lowermost craters, it seems plausible that the eruption commenced from the summit and crater formation propagated downslope to the coast.

The general sequence of events during the 1929 eruption was similar to that seen at flank-fissure eruptions elsewhere. Some points of similarity, summarized from Nakamura and others (1977) follow: (1) the flank-fissure eruption was immediately preceded by (or accompanied by) a summit eruption; (2) the eruptive fissure grew downslope and the eruptive activity persisted longer downslope, resulting in lava flows; and (3) the erupted magma had a relatively low viscosity.

In a model for flank-fissure eruptions from composite volcanoes with stable central pipe-like conduits, magma ascends the central conduit, if the magmatic pressure is not sufficiently relieved from a summit eruption, and a radial vertical fracture develops laterally and is filled with the source magma 


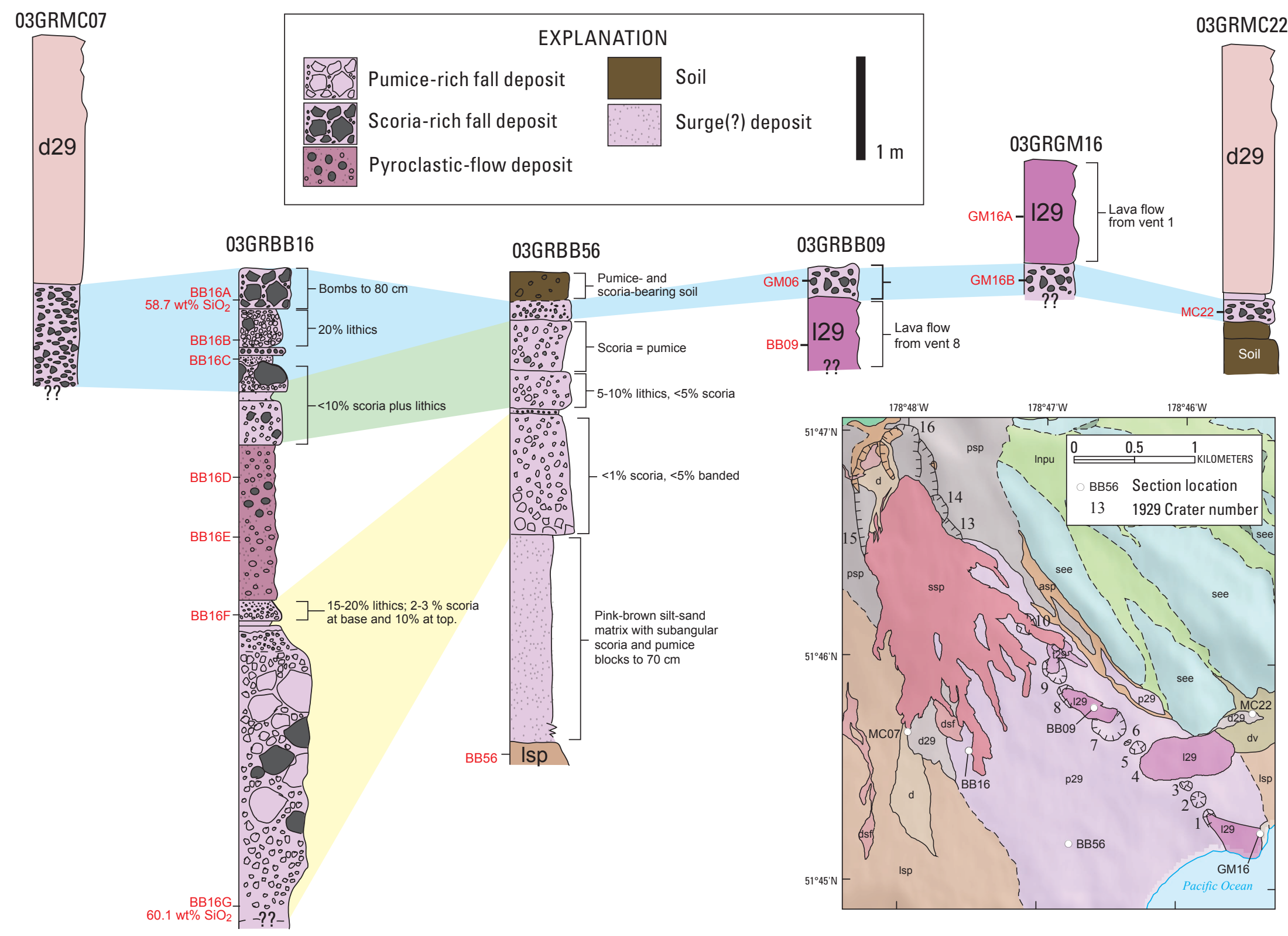

Figure 6. Stratigraphic sections showing deposits from the 1929 eruption of Mount Gareloi. Question marks at the base of a section indicate where the base of the 1929 deposit was not identified. Blue, green, and yellow fields connect units that potentially correlate between sections. Abbreviated sample numbers are shown in red; preface "03GR" has been removed from sample and site numbers for brevity. Index map shows locations of stratigraphic sections (abbreviated labels) on the southeast flank of Mount Gareloi. 


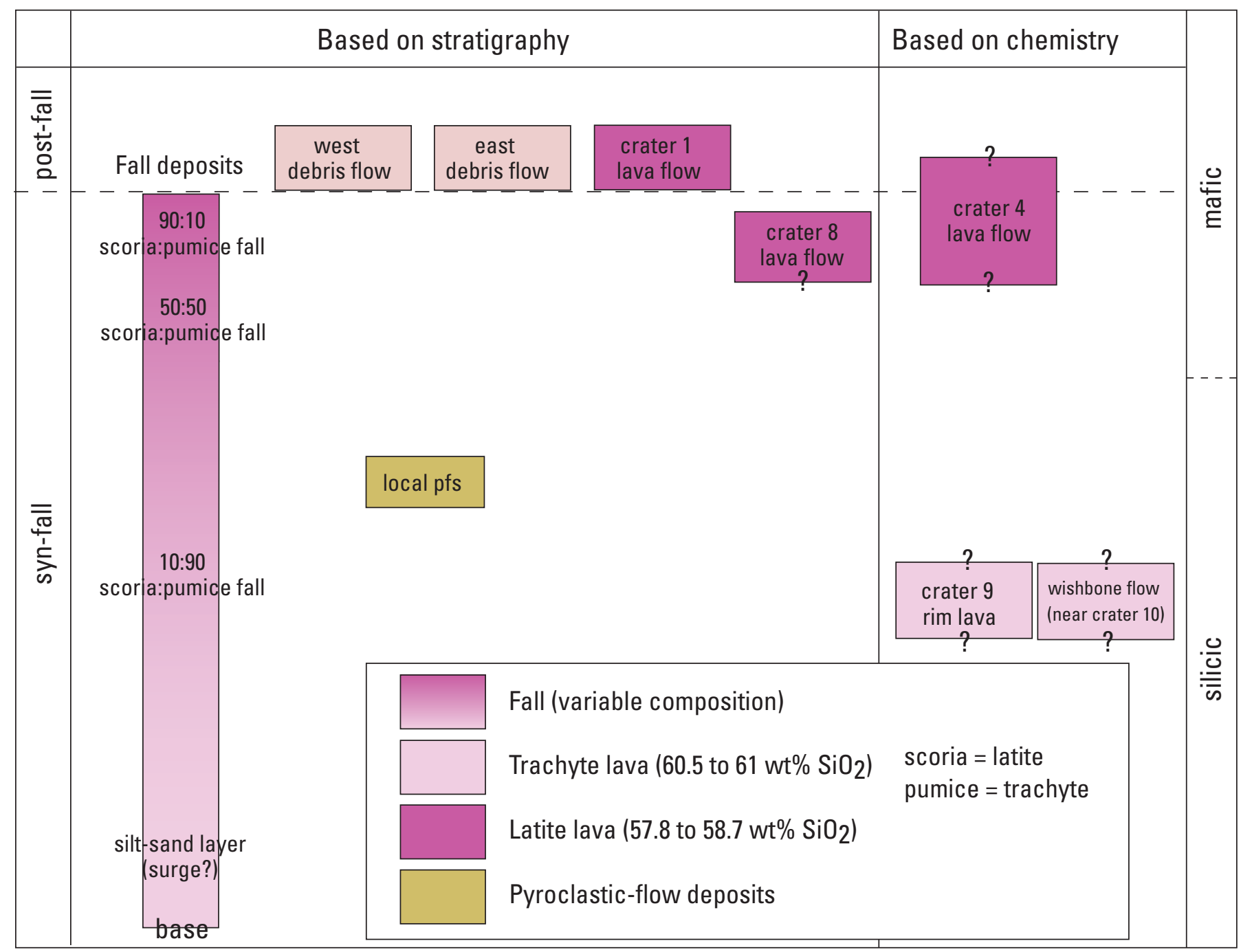

Figure 7. Diagram showing correlations between pyroclastic deposits, lava flows, and debris-flow deposits formed during 1929 eruption. Fall and pyroclastic-flow deposits compose unit p29; debris flows are unit d29; trachyte lava flows are unit t29; and latite lava flows are unit 129.

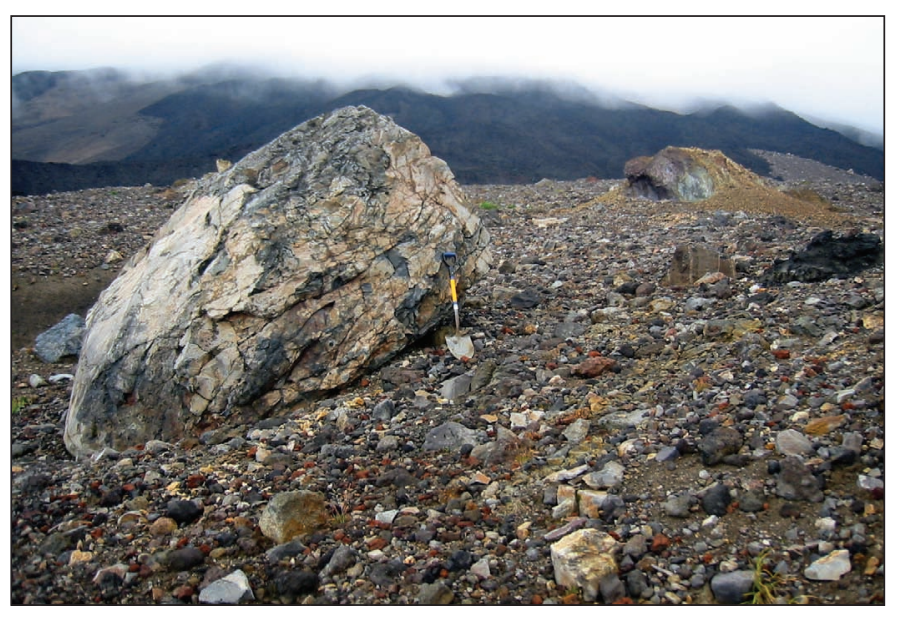

Figure 8. Photograph of debris-avalanche deposit (unit d29). Shovel is $1 \mathrm{~m}$ long. Photo by M.L. Coombs, USGS, August 2003.
(Nakamura and others, 1977). This model is consistent with the summit-then-flank pattern observed at Mount Gareloi.

\section{0-1980 South Peak Effusive Eruption}

One of the most prominent features on Mount Gareloi's south flank is a field of dark, sinuous, overlapping aa lava flows that emanate from the floor of the south peak crater. Unfortunately, no record exists to indicate exactly when these flows were emplaced. They are not depicted on an Army Map Service topographic map that was field checked in June 1950 but are visible in images from August 1980. The only reports of activity during this interval were during 1950 and 1952, when minor ash and fumes were observed (Jones, 1951, 1952).

The eruption produced an elaborate blocky lava flow (unit ssp) that extends down the southeast flank to $1,200 \mathrm{ft}$ asl. This lava flow is basaltic trachyandesite and contains abundant 
coarsely sieved plagioclase phenocrysts with minor clinopyroxene and olivine. The upper reaches of the flow, as well as the summit region, are covered by a layer of black scoria possibly erupted at the same time as the lava. The eruption likely occurred when the volcano was snow covered, because two scoria-rich debris-flow deposits on the south flank (unit dsf) probably formed during the eruption as hot scoria fell on snow.

\section{Flow(?)}

On September 4, 1987, a commercial pilot observed a narrow flow-like feature on the east flank of Mount Gareloi that extended from the north crater rim at 4,900 $\mathrm{ft}$ altitude down to at least 3,200 ft, below which it was obscured by clouds. Steam rose $100 \mathrm{~m}$ above the deposit and the crater was vigorously steaming (Smithsonian, 1987). The deposit, identified from the air in 2003 (fig. 9) but not sampled, is mapped as unit 187.

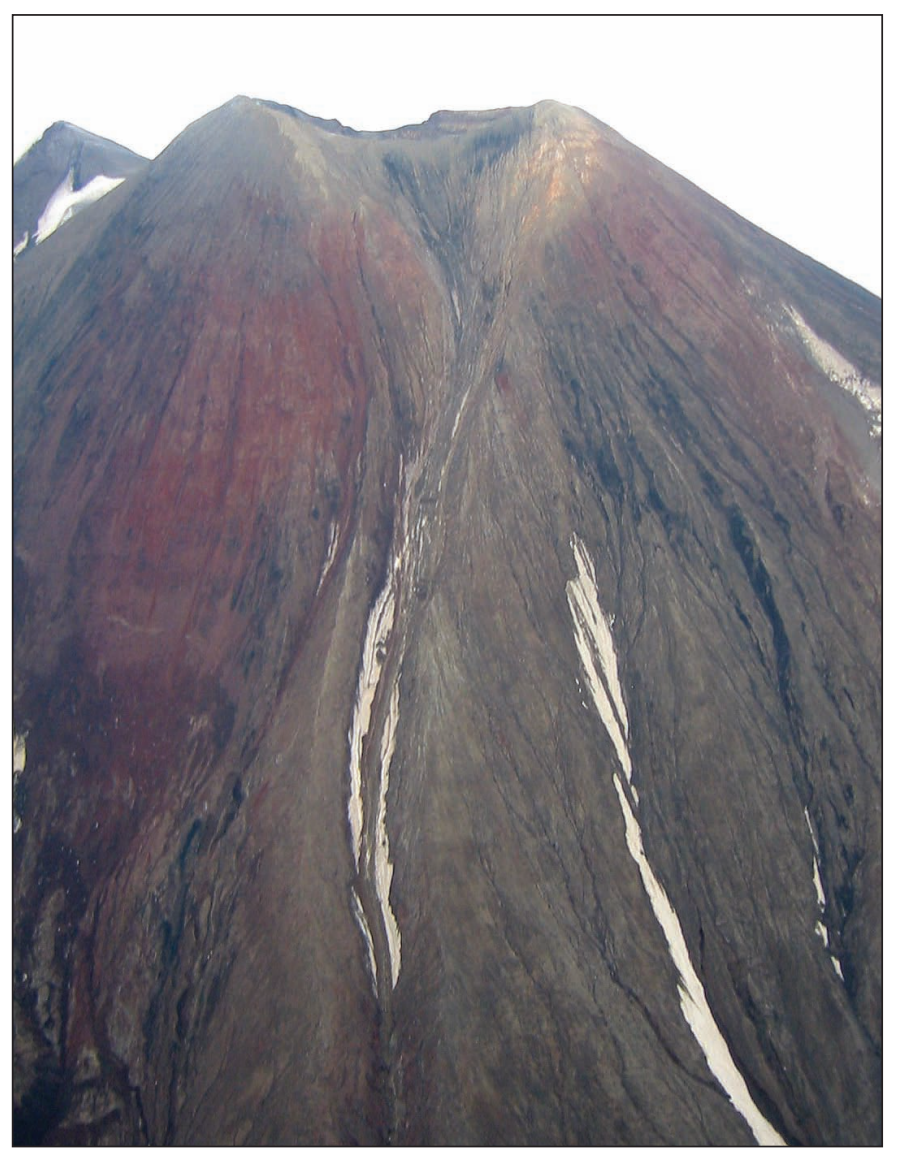

Figure 9. View of lava flow(?) formed during 1987 eruption. Photo by M.L. Coombs, USGS, August 2003.

\section{Recent Ash Eruptions}

After several decades of only fumarolic activity, the largest eruption since 1929 took place in August and September 1980. On August 8, the crew of a Northwest Orient Airlines plane spotted a plume, apparently ash, that rose to $35,000-40,000 \mathrm{ft}$ asl (Smithsonian, 1980). David Evans of the USGS reported that a seismic network on Adak recorded events from the west on August 8 and 9, though the exact location is not precise (Associated Press, 1980). No ash was reported to have fallen in Adak. Cloud cover obscured further observations after August 10. Evans said, "As far as we know, there was no lava eruption" (Associated Press, 1980). On August 10, airborne stratospheric sampling detected silicate ash and elevated sulfate concentrations at lat $54^{\circ}-60^{\circ} \mathrm{N}$., long $150^{\circ} \mathrm{W}$., at an altitude of $19.2 \mathrm{~km}$ (Sedlacek and others, 1981). This plume was plausibly a result of the August 8 eruption, based on wind direction and NOAA-6 satellite imagery (Sedlacek and others, 1981). The Smithsonian Institution (Smithsonian, 1980) reported renewed ash emissions as high as $6 \mathrm{~km}$ asl in September 1980. North peak's crater appeared to be the source of the 1980 eruption sequence, which is classified as Volcanic Explosivity Index (VEI) 3 based on plume height (Smithsonian, 1980).

On January 14, 1982, a magnitude 3.2-3.3 earthquake was recorded in the vicinity of Gareloi Island. On the following day, January 15, a 7- to 9-km-high eruption cloud was observed on satellite imagery (Miller, 1998).

Evan Klett, of the U.S. Fish and Wildlife Service, was traveling aboard a Reeve Aleutian Airways Inc. 727 Boeing Jet at 14:30 AKDT on August 17, 1989, flying from Shemya Island to Adak Island, when he observed a grayish to black tephra plume that was about $700 \mathrm{~m}$ above north peak's crater (Reeder, 1992). The plume covered the top of the north peak crater, which prevented Klett from seeing down into it. No other observations of this event exist.

On September 27, 1996, the Aviation Weather Unit in Alaska received a pilot report of a minor eruption of ash and steam at Mount Gareloi (Smithsonian, 1996). The pilot reported that the plume rose to $1,500 \mathrm{~m}$ above the summit. It was not visible on infrared satellite imagery, suggesting that it may not have ascended that high. As late as December 5 of that year, AVO had learned of no further sightings of activity at Mount Gareloi.

\section{Fumarolic Activity}

Both the south peak and north peak craters of Mount Gareloi have been sites of hydrothermal activity. Photos from 1942 and 1986 show billowing white steam emanating from the north crater, but since 2003 this crater has been snow filled and cold. Observations since 2003 have shown an area of warm ground, sulfur deposition, and diffuse steaming on the west rim of the south peak crater between approximately 4,200 and 4,600 ft asl.

\section{Composition of Erupted Products}

Prior to this study, no analyses of Mount Gareloi lavas existed, though Coats suggested that most eruptive products were andesitic to basaltic in composition. We have analyzed 74 
lava and scoria samples collected in 2003, including samples from most of the mapped units, for major and trace elements (appendix 1, file at http://pubs.usgs.gov/sim/3145). These analyses were made for the purpose of understanding magmatic diversity at the volcano, correlating syn-eruptive map units, and looking for evolutionary trends.

Mount Gareloi lavas range from 51.3 to 62.7 wt. percent $\mathrm{SiO}_{2}$. Silica-variation diagrams (fig. 10) clearly reveal that most analyzed lavas from Mount Gareloi fall outside of the normal range of compositions for Aleutian lavas. On a total alkalis versus silica diagram, most Mount Gareloi rocks are shoshonites and latites as defined by LeMaitre (2002). These lavas are high-K tholeiites, which have high values of large-ion lithophile elements and high field-strength elements and low $\mathrm{MgO}$ for a given silica content, and include rocks from the oldest and youngest units on the island and lavas from both north and south peaks. Products of the 1929 eruption form the most differentiated end of this enriched trend. Phenocryst phases in all lavas are plagioclase and clinopyroxene, with minor olivine and rare hornblende.

An exception to this enriched trend are lavas from unit asp - andesite flows from south peak. Several lava samples from this unit are calc-alkine andesites with approximately 62 wt. percent $\mathrm{SiO}_{2}$ and major- and trace-element abundances similar to or lower than other Aleutian andesites. They contain a phase assemblage of plagioclase, clinopyroxene, orthopyroxene, and oxides.

A single gabbroic bomb, sample 03GRBB22, has $45.2 \mathrm{wt}$. percent $\mathrm{SiO}_{2}$ and low values of incompatible elements. It contains plagioclase, clinopyroxene, olivine, and biotite.
The extreme enrichment in incompatible elements in many of the Mount Garleoi lavas can be explained by slight enrichment in the most mafic lavas followed by fractional crystallization. Initial enrichment in the more mafic erupted magmas could have been caused by additions of fluid, sediment, or sediment melt in the magmatic source region of the mantle wedge. The two very different compositional trends, interleaved in time and not spatially distinct, suggest that two or more sources fed magmas at this small volcano.

\section{Acknowledgments}

We thank Maritime Helicopters and the crew of the Maritime Maid (Bill Choate, Joe Christman, Jeannie Duran, and Dave Throop), who made our boat-based helicopter work such a success in 2003. We especially thank helicopter pilot Bill Springer, without whom most of the ground studied to produce this report would still be terra incognita. Andy Calvert's ages were critical in understanding Mount Gareloi's geology. Cheryl Cameron compiled the extremely useful historical eruption database for the Aleutian Arc. Evan Thoms provided essential GIS assistance. John Paskievitch expertly arranged many of the logistics for the 2003 field season. Reviews by Julie DonnellyNolan, and, in particular, Mike Clynne greatly improved the map. 

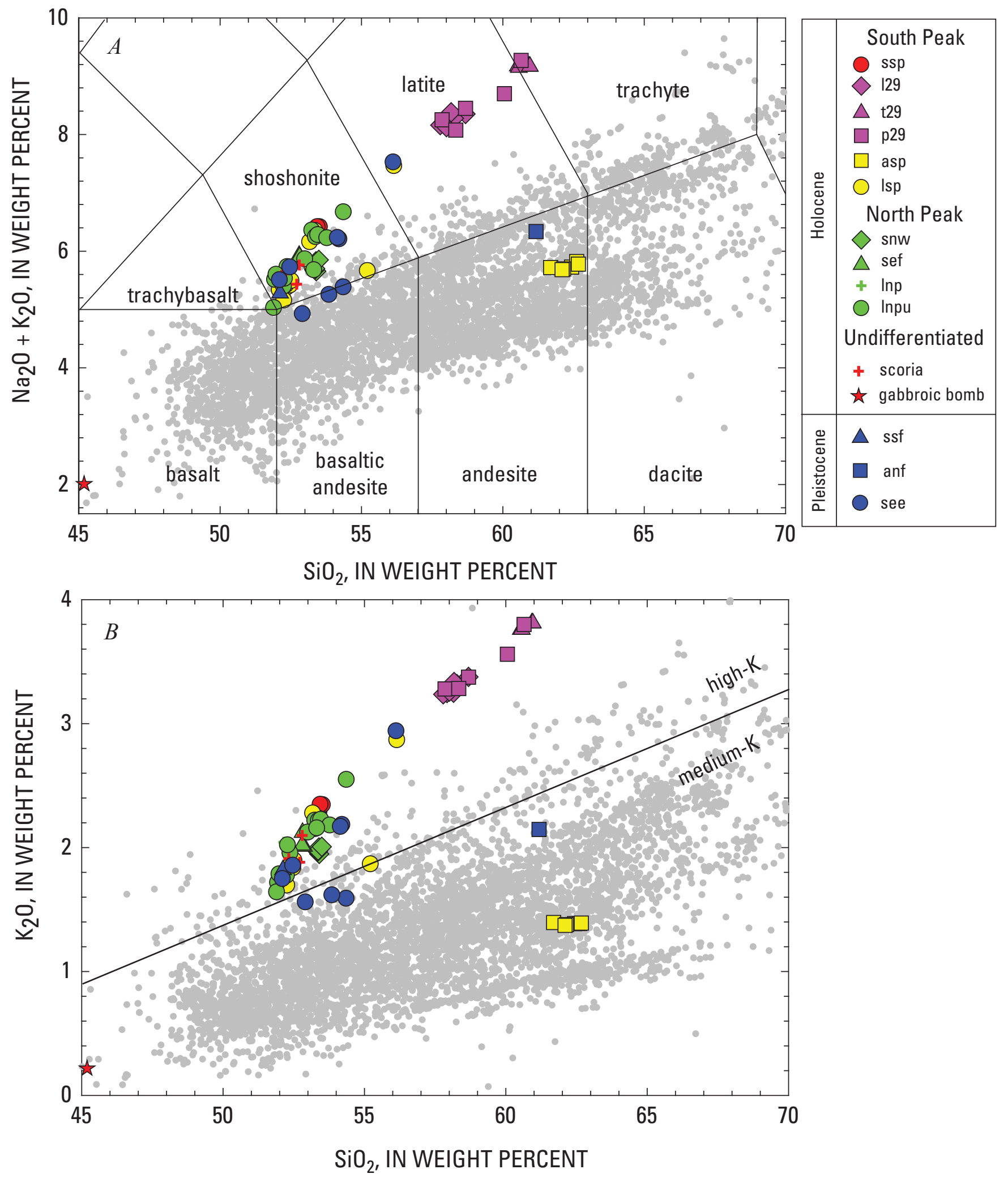

Figure 10. Variation diagrams showing compositions of Mount Gareloi rocks compared to other Aleutian lavas (in gray). $A$, Total alkalis versus $\mathrm{SiO}_{2}$. Classification scheme from LeMaitre and others (2002). Mount Gareloi lavas that fall in the basaltic trachyandesite and trachyandesite fields can be further classified as shoshonite and latite, respectively, because they contain $\mathrm{Na}_{2} \mathrm{O}-2.0<\mathrm{K}_{2} \mathrm{O} . B, \mathrm{~K}_{2} \mathrm{O}$ versus $\mathrm{SiO}_{2}$. $C, \mathrm{Fe} 0^{*} / \mathrm{MgO}$ versus $\mathrm{SiO}_{2}$. Tholeiitic-calcalkaline boundary from Miyashiro (1974). $D, \mathrm{Zr}$ (in ppm) versus $\mathrm{SiO}_{2}$. Other Aleutian data from Alaska Volcano Observatory database (Chris Nye, personal commun., 2008). 

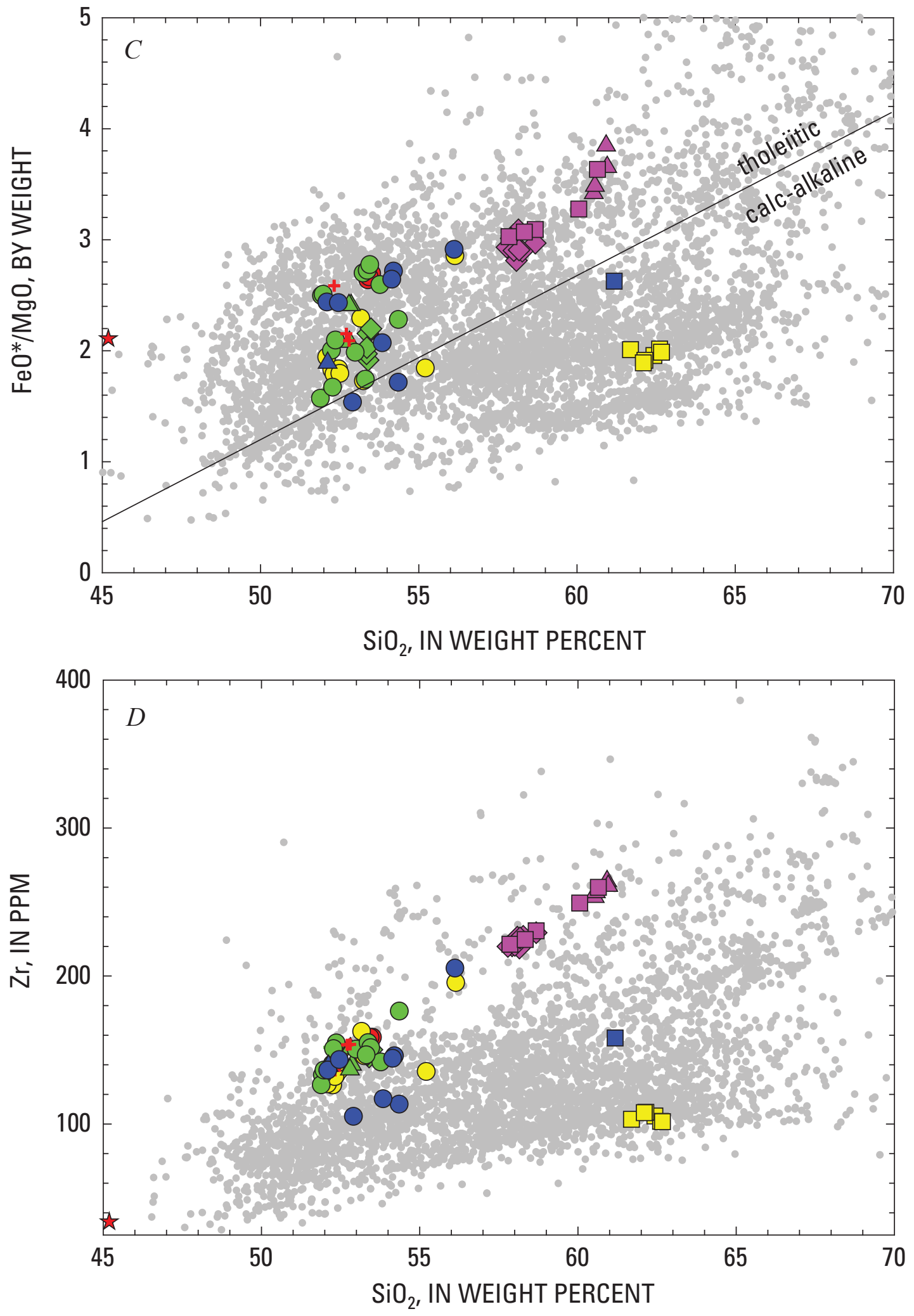


\section{DESCRIPTION OF MAP UNITS}

[All units on Gareloi Island are Quaternary. Map units have been organized according to age, but also according to eruptive vent - either south peak or north peak. The approximate time equivalence of units from the two vents is portrayed in the Correlation of Map Units on the map sheet. Units for which chemical analyses are available have been assigned rock names based on the scheme of LeMaitre (2002), with appropriate mineral modifiers. Where available, we included ranges of $\mathrm{SiO}_{2}$ and total alkalis $\left(\mathrm{K}_{2} \mathrm{O}+\mathrm{Na}_{2} \mathrm{O}\right)$ for each unit, in wt. percent. Descriptions of phenocrysts, which are defined as crystals $\geq 0.5 \mathrm{~mm}$ in length, were determined by observations of both hand specimens and thin sections. In addition, a subset of thin sections has been point counted]

\section{SURFICIAL DEPOSITS}

d Debris-flow deposits (historic) - Recent, thin $(<<1 \mathrm{~m})$ deposits of scoria-rich debris. Three exposures are on south flank at roughly 1,200 and 4,000 ft asl and on north flank at 2,300 $\mathrm{ft}$ asl. May have been emplaced at same time as dsf. All deposits very young; uppermost deposit on south flank overlies ssp

b Beach deposits (Holocene) - Cobble pocket beaches on east and south coastline of island

dv Viscous debris-flow deposits (late Holocene) - Poorly sorted, heterolithologic, massive deposits are several meters thick and consist of sandy matrix with dense lava clasts as large as boulder size. Two exposures are at 900 and $100 \mathrm{ft}$ asl on south flank. Eastern of two exposures underlies d29 and overlies Isp

\section{HOLOCENE VOLCANIC ROCKS-SOUTH PEAK}

csp Altered crater rocks of south peak (Holocene) - Altered, layered lavas and pyroclastic rocks exposed on steep west crater wall of south peak. This alteration zone coincides with a fumarole field that steamed vigorously during visits in 2003, 2005, and 2010. Rocks in this area are yellow, green, white, and light gray and have apparently undergone extensive hydrothermal alteration, which is strongest within fragmental beds. Unaltered equivalents are units Isp, asp, and psp

psp Pyroclastic rocks of south peak (Holocene) - Scoria, sand, and gravel deposits on uppermost reaches of south peak. Much of surface of and around south peak consists of an $\sim 1$-m-thick unit of loosely consolidated black scoria fall, with lapilli to $40 \mathrm{~cm}$ in diameter. Beds of variably altered fragmental breccias and fall deposits are exposed in uppermost walls of south peak crater. Likely late Holocene to historic in age. Overlies units asp and Isp; overlain by unit ssp

ssp Shoshonite lava-flow field of south peak crater (historic) - Composition: $53.4-53.5 \% \mathrm{SiO}_{2}$; $6.3-6.4 \%$ total alkalis (number of analyses, $n=4$ ). A field of dark-gray to black porphyritic augite-olivine shoshonite aa lava flows emanating from central floor of south peak crater, reaching $2.5 \mathrm{~km}$ down flank of volcano; they cover a total area of $1.63 \mathrm{~km}^{2}$. Field consists of numerous overlapping, sinuous flow fingers, most with well-developed flow levees. Some flow fingers follow gullies that have been cut into the 1929 pyroclastic apron. Height of flow levees ranges from 4 to $10 \mathrm{~m}$. Total volume of flow field is estimated to be $0.01-0.02 \mathrm{~km}^{3}$. Flows completely cover craters 11 and 12 from the 1929 eruption and partially cover craters 10, 13, and 14. Phenocrysts: $20 \%$ plagioclase, $3 \mathrm{~mm}$ across; $3 \%$ augite, $1 \mathrm{~mm}$ across; $2 \%$ olivine, $\leq 1 \mathrm{~mm}$ across. Date of their eruption is unknown, though it must have postdated 1950 and predated 1980, on the basis of bracketing field work and photographs. Upper reaches of the flow are covered by dark scoria, but this fall layer is not extensive. Overlies units p29, 129, d29, and dsf

dsf Debris-flow deposits of south flank (historic) - Two localized, thin debris-flow deposits, likely emplaced during early phase of eruption that produced unit ssp. One southwest of ssp flowed down west flank of south summit, consists of scoria (both brick-red oxidized and black), and forms a braided pattern on the underlying 1929 pyroclastic apron. A second, smaller deposit occurs just downslope of westernmost fingers of ssp. Both deposits are thin and probably ephemeral, preserved only because of their relative youth. They suggest that shoshonite flows of unit ssp, and accompanying tephra, were emplaced while snow was present in south crater 
Debris-flow deposits (1929) - Two small, poorly sorted fragmental deposits associated with 1929 eruption. Westernmost is a localized heterolithologic debris-flow deposit, maximum thickness unknown, that thins to $1 \mathrm{~m}$ thick at its margins. On its western edge, it overlies scoria fall of p29, indicating that it was emplaced late in 1929 sequence. Matrix is sand and gravel and contains clasts as large as $5 \mathrm{~m}$ in diameter. Many blocks are hydrothermally altered clastic rocks (breccias or some layered rocks) that are derived from units csp and psp. The most altered blocks are crumbling into rubble mounds. Smaller clasts in deposit are variably oxidized dense lavas and scoria, but none appear to be juvenile pyroclasts. Largest blocks extend downslope beyond visibly gray matrix of flow. An eastern deposit is smaller, nearly monolithologic, and spreads out from a channel at the northwestern point of unit 129 that erupted from crater 4. A section exposed in a gully wall shows that unit d29 is as thick as $3 \mathrm{~m}$, poorly sorted, and has a sandy matrix, with some discontinuous pumice-rich layers near its base. Top half of unit is especially rich in angular, buff-colored pumice bombs to $70 \mathrm{~cm}$ and is likely derived from unit p29. No hydrothermally altered blocks were seen in this deposit. Both deposits overlie unit p29

Pyroclastic deposits (1929) - Composition: $58.7-60.6 \% \mathrm{SiO}_{2} ; 8.1-9.3 \%$ total alkalis $(\mathrm{n}=5)$. Porphyritic augite-olivine trachyte and latite fall, surge, and pyroclastic-flow deposits from 1929 eruption. Strongly directed to south-southeast, thinning over short distances in other directions. Mapped contacts are approximate and show extent of deposit that thickly mantles and obscures underlying morphology. A significant portion of tephra was deposited offshore. No 1929 deposits were identified on north flank of island. Cut by multiple, several-meterdeep gullies that expose its internal stratigraphy. Fall deposits, at least $7 \mathrm{~m}$ thick and 2.5 $\mathrm{km}$ from the south peak crater, consist of buff to gray trachyte pumice, capped by dark gray latite scoria. Within 1929 craters, interbedded with units t29 and I29. Overlies unit Isp; overlain by units d29 and ssp Porphyritic augite-olivine trachyte aa lava found as flow effused from crater 7 and within walls of crater 6 of 1929 eruption. Phenocrysts: $10 \%$ plagioclase, $1-3 \mathrm{~mm}$ across; $3-5 \%$ augite, generally $1 \mathrm{~mm}$ across; $1-3 \%$ olivine, generally $1 \mathrm{~mm}$ across. Clots that include all phenocryst phases range to $5 \mathrm{~mm}$. Emplaced during first half of 1929 eruption on basis of compositional similarity to earliest fall deposits of unit p29

I29 Latite lava flows (1929) - Compositon: $57.8-58.3 \% \mathrm{SiO}_{2}, 8.1-8.4 \%$ total alkalis $(\mathrm{n}=8)$. Porphyritic augite-olivine latite. Small-volume, thin blocky lava flows that effused from lower craters $(1,4,5)$ of the 1929 fissure eruption. Lower two flows are already heavily vegetated. Largest flow, from crater 4, exhibits flow ridges that range to several meters in thickness. Internal stratigraphy, exposed only in lowest flow that has been eroded at the coastline, consists of a massive interior above a vesicular rubbly breccia and below a thicker upper flow breccia made of blocks as large as $1 \mathrm{~m}$ in diameter. Flow interior is light gray and breccias are dark gray and variably reddish. Phenocrysts: $7 \%$ plagioclase, generally $1-2 \mathrm{~mm}$ across, rarely to $3 \mathrm{~mm} ; 3 \%$ augite, $1-3 \mathrm{~mm}$ across; $1 \%$ olivine, $\leq 1 \mathrm{~mm}$ across. Emplaced during second half of 1929 eruption on basis of compositional similarity to latest fall deposits of unit 229

Andesite of south peak (late Holocene(?)) - Composition: $61.7-62.7 \% \mathrm{SiO}_{2}, 5.7-5.8 \%$ total alkalis $(\mathrm{n}=6)$. Augite-hypersthene andesite lava that partially caps south peak crater rim and crops out due west and southeast of south peak. Lava is dark gray and glassy with conchoidal fracture but lighter gray on weathered surface than other young flows. These flows are unusual for Mount Gareloi because they follow a medium-K, calc-alkaline trend. They have highest silica content of any analyzed Mount Gareloi rocks. Phenocrysts: 20-25\% plagioclase, generally as large as $1 \mathrm{~mm}$ (rarely to $3 \mathrm{~mm}$ ); $2 \%$ augite, as large as $1 \mathrm{~mm}$ across; $2 \%$ hypersthene, as large as $0.5 \mathrm{~mm}$ across. One of the few Mount Gareloi units to contain orthopyroxene. Flows have well-developed, $\sim 15$-m-high levees; interior of flows is $\sim 10 \mathrm{~m}$ thick. West flow is morphologically young and is not thickly covered by pyroclastic debris. Lowest kilometer of length is covered in vegetation similar to that seen on lower-elevation 1929 lava flows. Tight compositional clustering suggests emplacement during a single eruption. Overlies unit Isp; overlain by unit psp

Isp Lavas of south peak (Holocene) - Composition: $52.1-56.1 \% \mathrm{SiO}_{2} ; 5.2-7.5 \%$ total alkalis $(\mathrm{n}=10)$. Nearly aphyric to porphyritic augite-olivine shoshonite to latite. Multiple young 
undivided lava flows erupted from south peak. Lavas contain as much as $25 \%$ plagioclase phenocrysts and as much as several percent augite plus olivine. Where possible on map, internal flow boundaries divide individual flow lobes. These lavas occur over a sector of the island from the northwest to the south. On island's southwest flank, they clearly flow unconformably over deeply eroded shoshonite lavas of the early edifice. On west, they cover a broad expanse and merge to northwest with young lavas from north summit. To south, they probably underlie most deposits from 1929 eruption. On the basis of intact flow morphology, they are likely Holocene in age. Two lava samples from unit Isp that crop out beneath unit $d v$ on the southeast coast yield ${ }^{40} \mathrm{Ar} /{ }^{39} \mathrm{Ar}$ ages of $0.3 \pm 1.4$ and $1.8 \pm 4.5 \mathrm{ka}$, suggesting they are both latest Holocene in age. Overlies units Inpu and see; overlain by units asp, psp, and p29

\section{HOLOCENE VOLCANIC ROCKS-NORTH PEAK}

I87 Lava flow (1987) - Thin finger of lava(?) that reaches from east rim of north peak crater down to 3,200 ft asl; consistent with description of flow observed on September 4, 1987, by a commercial pilot, who described a narrow flow-like feature on east flank that extended from north crater rim at $5,000 \mathrm{ft}$ asl down to at least $3,500 \mathrm{ft}$, where it became obscured by clouds. Steam rose hundreds of feet above flow and crater was vigorously steaming (Smithsonian, 1987)

pnp Agglutinate, spatter, and pyroclastic deposits of north peak (Holocene; historic) - Primary pyroclastic deposits that cover upper flanks of north peak. From summit to approximately $100 \mathrm{ft}$ below, this unit consists of fine gray mud, probably phreatic in origin, scattered with prismatically jointed bombs as large as $1 \mathrm{~m}$ in diameter, some hydrothermally altered. Small scarps expose layered lapilli and ash-fall deposits beneath this mantle. At slightly lower elevations on north flank of north peak, this unit appears to consist of variably oxidized fall and agglutinate deposits, though steep terrain prevented direct observation. Also includes interbedded, variably altered lava flows and pyroclastic deposits exposed in walls of north peak crater and along a scarp high on north peak's west flank. Lowest extent on northwest flank consists of poorly sorted sand and gravel deposits

Inp Sheet lava field of north peak (Holocene) - Composition: $52 \% \mathrm{SiO}_{2} ; 5.6 \%$ total alkalis $(\mathrm{n}=1)$. Augite-olivine shoshonite with seriate texture of continuously varying crystal sizes. Morphologically smooth flow field of gray lavas that are 1-2 $\mathrm{m}$ thick, have smooth surfaces, and are filled with vuggy vesicles to $4 \mathrm{~mm}$ in diameter. Phenocrysts: $20 \%$ plagioclase, as large as $2 \mathrm{~mm}$ across; $4 \%$ augite, as large as $2 \mathrm{~mm}$ across; $3 \%$ olivine, as large as $1 \mathrm{~mm}$ across. Lavas in this unit bank up against, and are younger than, lavas of unit snw and occupy a discrete region on upper northwest flank below north peak's summit. Overlies unit Inpu; overlain by $1-\mathrm{m}$-thick section of soil and tephra

pef Lithic pyroclastic-flow deposits of east flank (Holocene) - Package of thin $(<2 \mathrm{~m}($ ?)), lithicrich pyroclastic-flow and interbedded surge deposits on east flank of north peak. Forms distinctive, smooth, pavement-like surface on top of unit Inpu lava flows. Contains dense but likely primary cauliflower-shaped bombs of plagioclase-pyroxene-olivine basalt to $1.3 \mathrm{~m}$ and scoria clasts commonly to $25 \mathrm{~cm}$. May be more extensive than mapped. Overlies units Inpu and see. Age relative to units sef, snw, and Inp unknown

snw Shoshonite lavas of northwest flank (late Holocene) - Composition: $53.4-53.5 \% \mathrm{SiO}_{2}$; $1.95-2.0 \% \mathrm{~K}_{2} \mathrm{O}(\mathrm{n}=5)$. Two prominent porphyritic olivine-augite shoshonite lava flows that erupted from north peak. Lava flows are medium gray, massive, and $>4 \mathrm{~m}$ thick and have prominent levees. They are likely coeval, because they are compositionally similar. Flows fall just below main Mount Gareloi trend on silica- $\mathrm{K}_{2} \mathrm{O}$ variation diagram (fig. 10B). Phenocrysts: $20-25 \%$ plagioclase, $1-3 \mathrm{~mm}$ across; $5 \%$ augite, $1-2 \mathrm{~mm}$ across; $2 \%$ olivine, as large as $1 \mathrm{~mm}$ across. Clots of olivine and augite are common and as much as several millimeters in size. Top of northernmost flow is covered by $1 \mathrm{~m}$ of scoria-rich sand and gravel. One bomb on flow is $2 \mathrm{~m}$ in length. Both flows are topped by pods of red-brown soil as thick as $15 \mathrm{~cm}$. In one locality, south flow is covered by $90 \mathrm{~cm}$ of interlayered soil and ash. Upper reaches of the two flows are covered by unit pnp; they overlie unit Inpu

sef Shoshonite lavas of east flank (late Holocene) - Composition: $52.8-52.9 \% \mathrm{SiO}_{2} ; 5.8-5.9 \%$ total alkalis $(\mathrm{n}=3)$. Porphyritic augite-olivine shoshonite. Two leveed lava flows reach from 
north peak's summit to coastline, forming prominent lava deltas. Phenocrysts: $12-15 \%$ plagioclase, generally to $3 \mathrm{~mm}$ across; $1-5 \%$ augite, to $2 \mathrm{~mm}$ across; $\sim 1 \%$ olivine, to $1 \mathrm{~mm}$ across. On the basis of morphology and composition, flows appear to be similar in age, though northern of two is slightly richer in augite phenocrysts. Flows overlie Holocene lavas of unit Inpu that fill sector-collapse scarp on east flank

Inpu Lavas of north peak, undivided (Holocene) - Composition: 52-54.4\% $\mathrm{SiO}_{2} ; 5.0-6.7 \%$ total alkalis ( $\mathrm{n}=11)$. Porphyritic augite-olivine shoshonites. Lavas fall into two groups: some are plagioclase rich and contain as much as $25 \%$ plagioclase and only small $(\sim 1 \%)$ amounts of augite and olivine; others, also with abundant plagioclase, have as much as several percent augite plus olivine. Contacts between individual flows (internal flow boundaries) are mapped where possible. Flows are extensive on northwest flank, cover an apparent sector collapse scar on east flank, and flowed over shoshonite of the early edifice on volcano's southeast and northeast flanks. Northeast flow field of unit Inpu appears to have erupted from a flank vent at approximately 2,600 ft asl. One arm of flow field reached the coastline, forming a lava delta $850 \mathrm{~m}$ wide and $<30 \mathrm{~m}$ high. Lava flow field is covered by $>1 \mathrm{~m}$ of soil, and its morphology is subdued accordingly. Older than units snw, sef, and Inp, with the possible exception of the northeast flow field. All lavas of unit Inpu are unmodified by glaciation or extensive erosion. One flow on east flank yielded an ${ }^{40} \mathrm{Ar} /{ }^{39} \mathrm{Ar}$ age of $6.1 \pm 1.0$ ka. Overlain by some lavas of unit Isp

\section{PLEISTOCENE VOLCANIC ROCKS}

Shoshonite of early edifice (Pleistocene(?)) — Composition: $51.9-54.4 \% \mathrm{SiO}_{2} ; 4.9-6.2 \%$ total alkalis $(\mathrm{n}=9)$. Porphyritic augite-olivine shoshonites and basaltic andesites. Eroded to deeply eroded lava flows. Limited sampling coverage means that unit is likely more compositionally or geologically varied than described here. Most lavas from this unit lie along a high-K trend and fall squarely in shoshonite field (fig. 10). Three lavas on the low-K trend were analyzed: 03GRBB52, 03GRBB57, and 03GRGM14 (appendix 1). First two are on southwest flank, third is on north flank. They are light-gray, blocky to massive lavas that compositionally lie on line between basaltic andesite and shoshonite (fig. 10A). Except for units ssf and anf, this unit forms most of undivided Pleistocene edifice. Steep, 650-m-tall cliff on the southwest coast strikes N. $45^{\circ} \mathrm{W}$., parallel to plate motion, and may be normal fault. Unit is undated and assumed to be Pleistocene on the basis of the high degree of erosion and unconformity between it and overlying units Isp and Inpu. A single ${ }^{14} \mathrm{C}$ date of a soil horizon at least $3 \mathrm{~m}$ above bedrock surface yields $1,090 \pm 70 \mathrm{yr}$ B.P.

ssf Shoshonite dome of south flank (Pleistocene) - Composition: $51.1 \% \mathrm{SiO}_{2}, 5.3 \%$ total alkalis $(\mathrm{n}=1)$. Augite-olivine shoshonite. Ash-fall-covered, rounded lava mound on south flank at $1,675 \mathrm{ft}$ asl. Compositionally similar to other shoshonites of the early edifice but distinctive in its highly vesicular texture, with large, wormy vesicles to $1 \mathrm{~cm}$ in diameter and light gray color. Some outcrops are columnar jointed. Phenocrysts: $15 \%$ plagioclase, $1-2 \mathrm{~mm}$ across; $5 \%$ augite, $1-3 \mathrm{~mm}$ across; $3 \%$ olivine, to $1 \mathrm{~mm}$ across. It is older than and surrounded by lavas of unit Isp

anf Andesite of north flank (Pleistocene) - Composition: $61.2 \% \mathrm{SiO}_{2}, 6.3 \%$ total alkalis ( $\mathrm{n}=1$ ). Porphyritic hornblende-augite-hypersthene andesite. Eroded lava dome or flow remnant at $700 \mathrm{ft}$ asl on north flank. Outcrop is knob $200 \mathrm{~m}$ in diameter. Phenocrysts: $25 \%$ plagioclase, as large as $3 \mathrm{~mm}$ across; $20 \%$ augite, as large as $1 \mathrm{~mm}$ across; $5 \%$ hornblende, as large as $2 \mathrm{~mm}$ across; $2 \%$ hypersthene, as large as $1 \mathrm{~mm}$ across; trace amounts of olivine. Lava is distinguished from other rocks of the older edifice by its lower-K composition, by its high phenocryst content $(\sim 50 \%)$, and by its phase assemblage of plagioclase, augite, amphibole, hypersthene, and olivine, in decreasing abundance. Only amphibole-bearing lava sampled from older edifice. Exposures are deuterically altered, with some mineralization in vugs. Alteration and subdued surface morphology suggest a Pleistocene age 


\section{References Cited}

Associated Press, 1980, Remote Alaska volcano blows its top: Anchorage Times, August 16, p. A3.

Caplan-Auerbach, J., and Prejean, S.G., 2005, High levels of non-eruptive seismicity at Mount Gareloi, Alaska: Eos, Transactions of the American Geophysical Union, Fall Meeting Supplemental, Abstract V33A-0673, v. 86, no. 52.

Coats, R.R., 1947, Reconnaissance geology of some western Aleutian Islands, Alaska: U.S. Geological Survey Alaskan Volcano Investigations Report 0002, p. 95-105.

Coats, R.R., 1950, Volcanic activity in the Aleutian Arc: U.S. Geological Survey Bulletin 974-B, p. 35-49.

Coats, R.R., 1956, Reconnaissance geology of some western Aleutian Islands, Alaska, in Investigations of Alaskan volcanoes: U.S. Geological Survey Bulletin 1028-E, p. 83-100.

Coats, R.R., 1959, Geologic reconnaissance of Gareloi Island, Aleutian Islands, Alaska, in Investigations of Alaskan volcanoes: U.S. Geological Survey Bulletin 1028-J, p. 249-256, 1 sheet.

Coombs, M.L., McGimsey, R.G., and Browne, B.L., 2008, Preliminary hazard assessment of Gareloi volcano, Gareloi Island, Alaska: U.S. Geological Survey Scientific Investigations Report 2008-5159, 26 p.

Coombs, M.L., White, S., and Scholl, D., 2007, Massive edifice failure at Aleutian arc volcanoes: Earth and Planetary Science Letters, v. 256, p. 403-418.

Engebretson, D.C., Cox, A., and Gordon, R.G., 1985, Relative motion between oceanic and continental plates in the Pacific Basin: Boulder, CO, Geological Society of America, v. 206, 59 p.

Finch, R.H., 1931, Notes from the Aleutian Islands: The Volcano Letter, v. 357, p. 2-3.

Geist, E.L., Childs, J.R., and Scholl, D.W., 1988, The origin of summit basins of the Aleutian Ridge-Implications for block rotation of an arc massif: Tectonics, v. 7, p. 327-341.

Gesch, D.B., Muller, J.-P., Farr, T.G., 2006, Foreword, in The shuttle radar topography mission-Data validation and applications: Engineering Remote Sensing, v. 72, p. 233-235.

Jicha, B.R., Scholl, D.W., Singer, B.S., Yogodzinski, G.M., and Kay, S.M., 2006, Revised age of Aleutian Island Arc formation implies high rate of magma production: Geology, v. 34, p. 661-664.

Jones, A.E., 1951, Aleutian volcanic activity: The Volcano Letter, v. 514, p. 6.

Jones, A.E., 1952, Aleutian volcanoes: The Volcano Letter, v. 516 , p. 8-9.

Kay, S.M., and Kay, R.W., 1994, Aleutian magmas in space and time, in Plafker, G., and Berg, H.C., eds., The Geology of Alaska, in Geology of North America: Geological Society of America, chap. 22, p. 687-722.

Kelemen, P.B., Yogodzinski, G.M., and Scholl, D.W., 2003, Along-strike variation in the Aleutian Island arc-Genesis of high $\mathrm{Mg \#}$ andesite and implications for continental crust, in Inside the subduction factory: American Geophysical Union Monograph 138, p. 223-276.
LeMaitre, R.W., 2002, Igneous Rocks - A classification and glossary of terms - Recommendations of the International Union of Geological Sciences Subcommission on the systematics of igneous rocks ( $2 \mathrm{~d}$ ed.): Cambridge, Cambridge University Press, $236 \mathrm{p}$.

Miller, T.P., McGimsey, R.G., Richter, D.H., Riehle, J.R., Nye, C.J., Yount, M.E., and Dumoulin, J.A., 1998, Catalog of the historically active volcanoes of Alaska: U.S. Geological Survey Open-File Report 98-582, 104 p.

Minster, B., and Jordan, T., 1978, Present-day plate motions: Journal of Geophysical Research, v. 83, p. 5331-5354.

Miyashiro, A., 1974, Volcanic rock series in island arcs and active continental margins: American Journal of Science, v. 274, no. 4, p. 321-355.

Nakamura, K., Jacob, K.H., and Davies, J.N., 1977, Volcanoes as possible indicators of tectonic stress orientation-Aleutians and Alaska: Pure and Applied Geophysics, v. 115, no. 1-2, p. 87-112.

Nichols, H., and Perry, R.B., 1966, Bathymetry of the Aleutian arc, Alaska: Washington, D.C., U.S. Coast and Geodetic Survey Monogram, v. 3.

Reeder, J.W., 1992, Gareloi: Bulletin of Volcanic Eruptions, v. 29, p. 70.

Scholl, D.W., Vallier, T.L., and Stevenson, A.J., 1987, Geologic evolution and petroleum geology of the Aleutian Ridge, in Scholl, D.W., Grantz, A., and Vedder, J.G., eds., Geology and resource potential of the continental margin of western North America and adjacent ocean basins-Beaufort Sea to Baja California: Houston, TX, Circum-Pacific Council on Energy and Mineral Resources, p. 124-155.

Sedlacek, W.A., Mroz, E.J., and Heiken, G., 1981, Stratospheric sulfate from the Gareloi eruption, 1980 - Contribution to the "ambient" aerosol by a poorly documented volcanic eruption: Geophysical Research Letters, v. 8, no. 7, p. 761-764.

Singer, B.S., Jicha, B.R., Leeman, W.P., Rogers, N.W., Thirlwall, M.F., Ryan, J., and Nicolaysen, K.E., 2007, Alongstrike trace element and isotopic variation in Aleutian Island arc basalt - Subduction melts sediments and dehydrates serpentine: Journal of Geophysical Research, v. 112, doi:10.1029/2006JB004897.

Smithsonian, 1980, Gareloi: Smithsonian Institution, Scientific Event Alert Network Bulletin, v. 05, no. 08, p. 7-8.

Smithsonian, 1987, Gareloi: Smithsonian Institution, Scientific Event Alert Network Bulletin v. 12, no. 08.

Smithsonian, 1996, Gareloi: Smithsonian Institution, Global Volcanism Network Bulletin v. 21, no. 10.

\section{Appendix 1. Whole-rock Compositions of Rocks from Mount Gareloi}

The whole-rock data, with accompanying sample locations and descriptions, is tabulated in an Excel spreadsheet file at http://pubs.usgs.gov/sim/3145 and is also included as a table in the ArcGIS geodatabase file. 